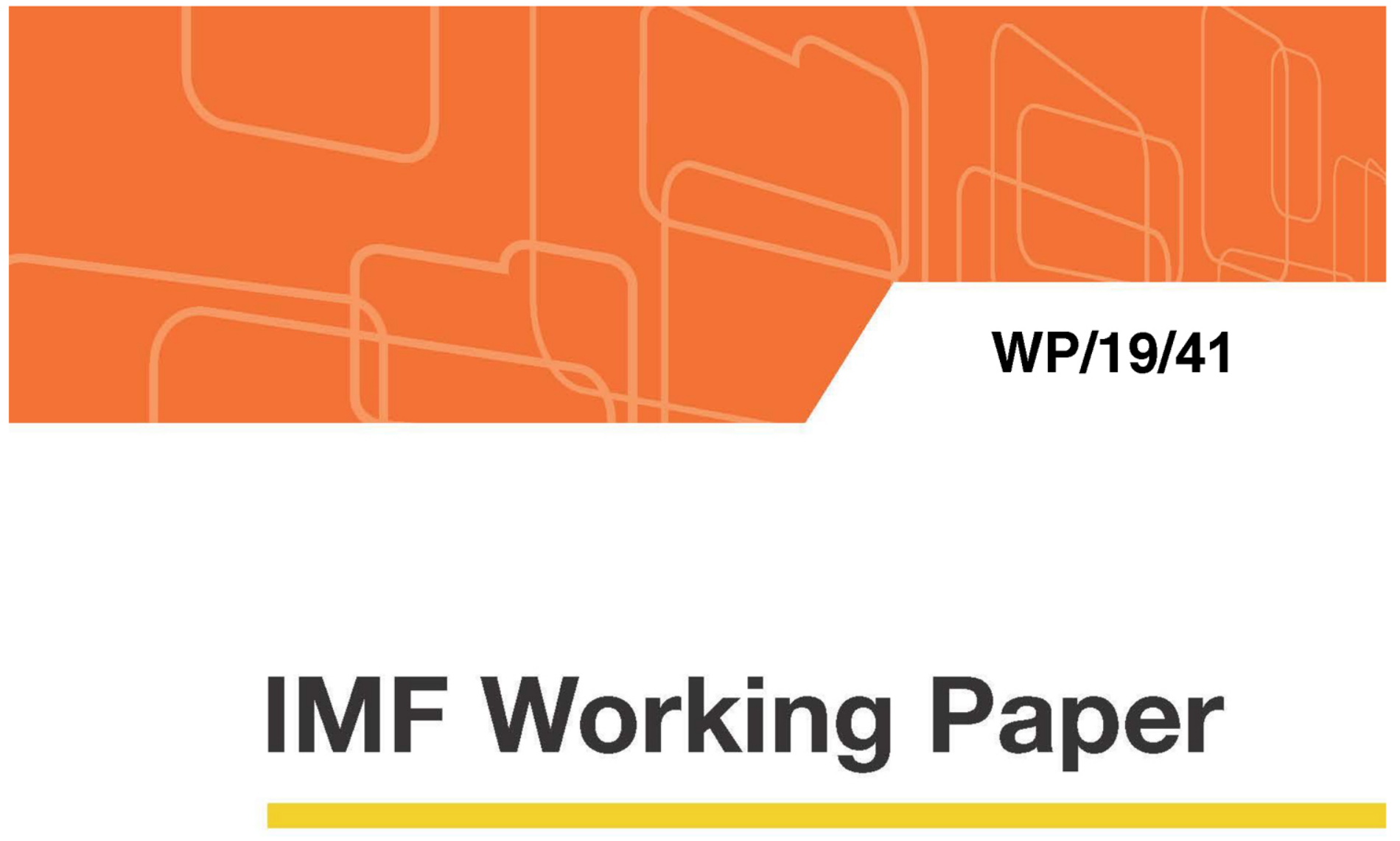

\title{
Macroeconomic Gains from Reforming the Agri-Food Sector: The Case of France
}

by Nicoletta Batini

IMF Working Papers describe research in progress by the author(s) and are published to elicit comments and to encourage debate. The views expressed in IMF Working Papers are those of the author(s) and do not necessarily represent the views of the IMF, its Executive Board, or IMF management. 


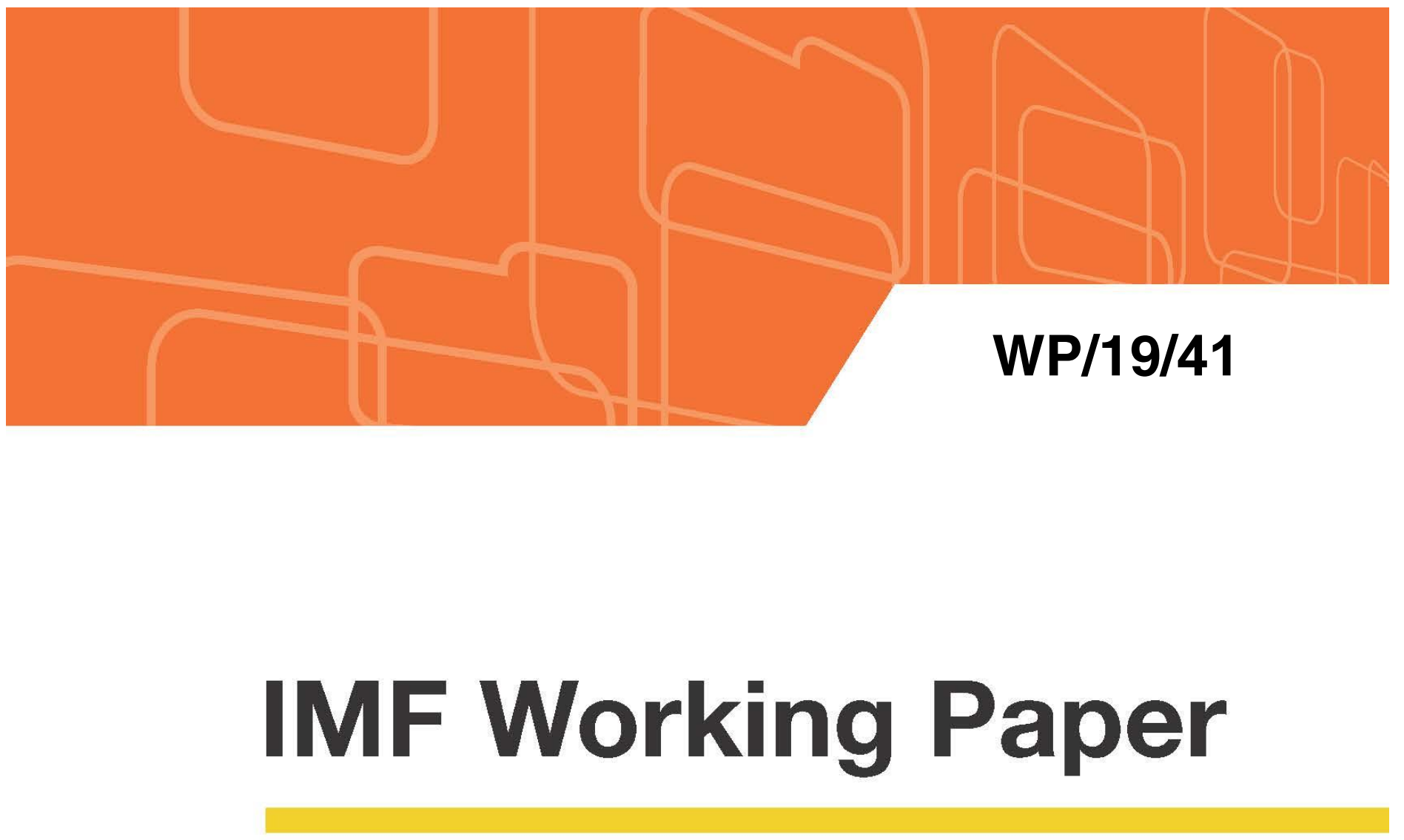

\section{Macroeconomic Gains from Reforming the Agri-Food Sector: The Case of France}

by Nicoletta Batini

IMF Working Papers describe research in progress by the author(s) and are published to elicit comments and to encourage debate. The views expressed in IMF Working Papers are those of the author(s) and do not necessarily represent the views of the IMF, its Executive Board, or IMF management. 


\title{
IMF Working Paper
}

European Department

\section{Macroeconomic Gains from Reforming the Agri-Food Sector:}

\author{
The Case of France ${ }^{1}$
}

\section{Prepared by Nicoletta Batini}

Authorized for distribution by Delia Velculescu

February 2019

\section{IMF Working Papers describe research in progress by the author(s) and are published to} elicit comments and to encourage debate. The views expressed in IMF Working Papers are those of the author(s) and do not necessarily represent the views of the IMF, its Executive Board, or IMF management.

\begin{abstract}
France is the top agricultural producer in the European Union (EU), and agriculture plays a prominent role in the country's foreign trade and intermediate exchanges. Reflecting production volumes and methods, the sector, however, also generates significant negative environmental and public health externalities. Recent model simulations show that a well-designed shift in production and consumption to make the former sustainable and align the latter with recommended values can curb these considerably and generate large macroeconomic gains. I propose a policy toolkit in line with the government's existing sectoral policies that can support this transition.

JEL Classification Numbers: E23, H23, I10, J17, J43, L66, L70, Q11, Q18, Q58, R14

Keywords: agriculture, growth, food policy, climate change, externalities, fiscal policy, diets Author's E-Mail Address: nbatini@imf.org

\footnotetext{
${ }^{1}$ I am grateful to Aquib Aslam, Pierre-Marie Aubert, Arnaud Buisse, Alessandro Cantelmo, Hélène Casset-Hervio, Julien Deroyon, Julien Fosse, Alice Gremillet, Thibault Guyon, Alex Klemm, Emmanuel Masse, Giovanni Melina, Berenger Mesqui, Christian Mumssen, Ian Parry, Philippe Pointereau, Xavier Poux, Philippe Quirion, Valerie Tó, Constance Valigny, and Delia Velculescu for sharing with me useful material and information and/or for conversations entertained during the preparation of this analysis. All errors are mine. The views expressed here are of the author and do not necessarily represent those of the International Monetary Fund or its Board.
} 


\section{FRANCE'S DEEP RURAL ROOTS}

1. For centuries, France has been one of the main agricultural centers of Europe and the sector has been a major source of jobs and exports. By the mid-19th century, about $2 / 3$ of all French workers were engaged in agriculture $(3 / 4$ of all rural workers). Traditional produces include, in order of importance, grains, wine grapes, dairy products, beef, sugar beets, and potatoes.

\section{Over time, shaped by technological advances, falling prices and national and} regional policies, the sector has become increasingly industrialized (Table 1). From the late 19th century, following the onset of the Industrial Revolution and price and trade developments, the sector has become increasingly industrialized, which resulted in a rural exodus that continued throughout the 20th century as productivity rose and rural income fell. In the mid-20st century, the process was accelerated by new EU regulation under the Common Agricultural Policy that incentivized integration to arrive at economies of scale sufficient to deal with lower prices and higher administrative costs. Industrialization has led to the concentration of supply, with the number of farms falling by a factor of 6 since 1860, a factor of 4 since 1955, and a factor of 2 since only $1990 .^{2}$

\section{By virtue of these developments, French agricultural output has increased} manifolds despite the drop in total land farmed. Average crop yields, and milk production have soared since the onset of industrialization, and labor factor productivity has accelerated, especially after WWII, at rates constantly superior than the rate of productivity advances in other sectors of the economy (Table 1 and Figure 1). After reaching even higher growth rates in the early $20^{\text {th }}$ century, productivity grew relentlessly by $1-2$ percent per year between the 1930 s and the 2000 s, before stabilizing in real terms.

\footnotetext{
2 See: Insee (2016). Agriculture in 2016. According to the 2010 Agricultural Census "large" farms (i.e. farms with an average gross product in excess of 100k euros) are now 40 percent of total farms from 12 percent in 1990 (on average farm sizes have grown by over 30 percent between 2000 and 2010).
} 


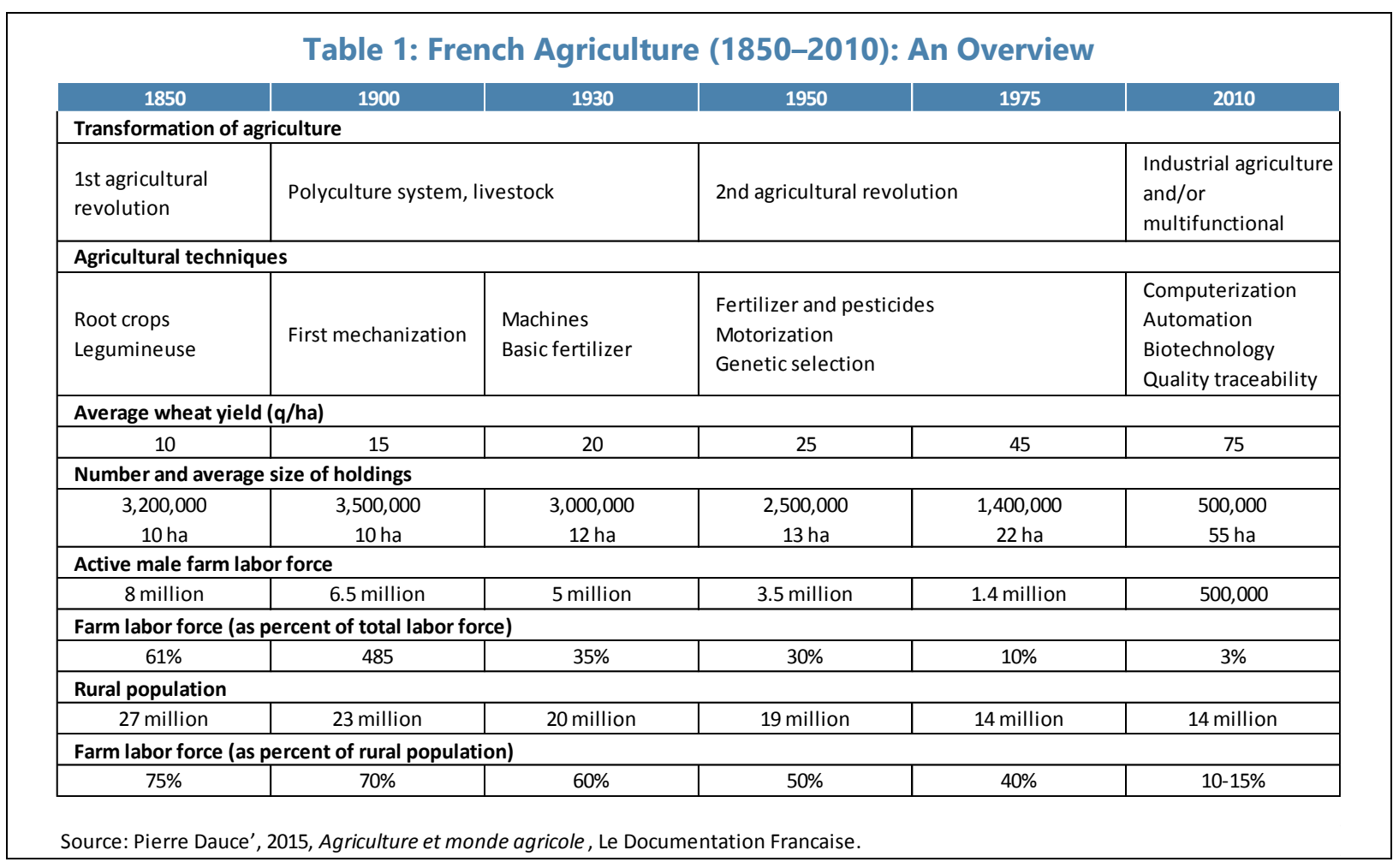

4. As productivity has increased much more rapidly than the value added generated by agriculture, employment has dropped dramatically over the past 100 years. The sector now contributes to less than 2 percent of GDP (from about 15 percent in the 1950s) - compared with about 19 percent for industry and 79 percent for services. Combined with the fast increase in agricultural productivity, the drop in value added resulted in a sizeable and permanent decline in farm-based, direct agricultural (full-time equivalent) employment, which now totals to less than 3 percent of total employment, down from over 30 percent in 1950, leading to a massive rural exodus. Even so, to date, about $1 / 3$ of the French total population (19.5 million) live in predominantly rural areas (Table 1 and Figure 1). And while farmers' income has held recently, mostly due to the decline in the number of farmers and farms, and to the increase in subsidies to farmers both from the state and from the EU, income distribution across farms has become significantly uneven, with most small farmers having to integrate farm income with other sources of income, ${ }^{3}$ and farmers' debt-to-income ratios continued to trend upwards in the past two decades (Figure 1).

\footnotetext{
${ }^{3}$ French farmers' income is also highly volatile - with swings by over a third to a half from one year to the next - and regionally diverse with areas like Champagne more prosperous than the EU27, EU15 and EUN10 regions, but other areas way below.
} 
Figure 1: Six Economic Facts about the French Agri-Food Sector

Once prominent, agriculture contribution to GDP and labor force has declined more than the agri-food industry.

Share of Agricultural and Agro-food Sector (1896-2010) (Percent)

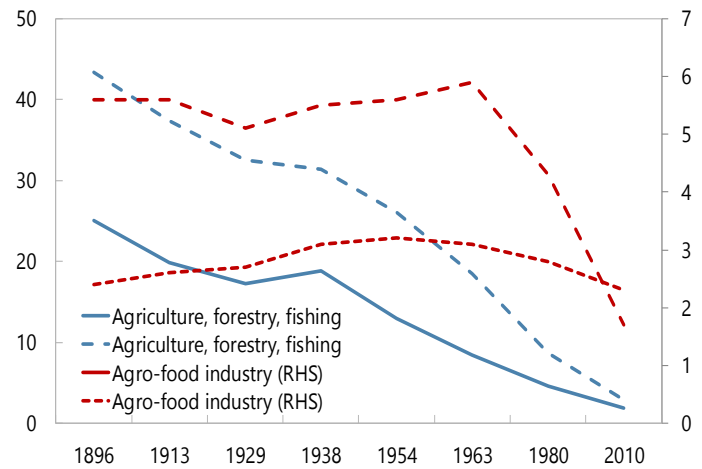

Notes: Solid line denotes share of GDP, dashed line denotes share of total labor force. Sources: Marchand and Thélot, and INSEE.

....as machines and chemical inputs took the place of agricultural workers.

Growth in Labor Productivity

(Value added per worker, annual percentage growth, period average)

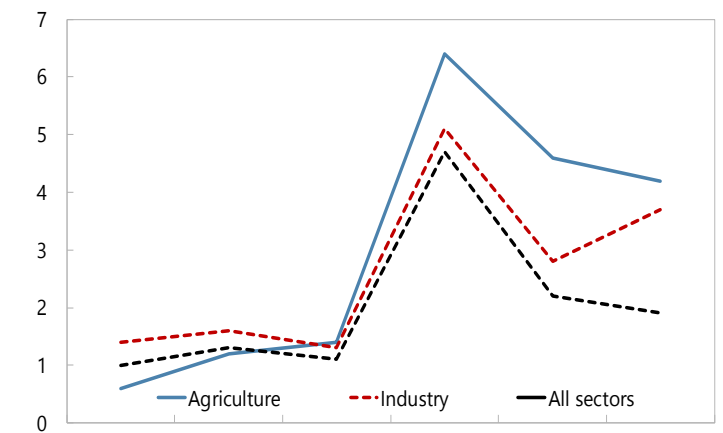

1831-1896 1896-1931 1931-1949 $1949-1973 \quad 1973-1989 \quad 1990-2007$

Sources: Marchand and Thélot, and INSEE.

And net farm income has fallen only little thanks to increasing market concentration and rising EU subsidies...

France: Net Entrepreneurial Income of Agriculture (Thousands of euros)

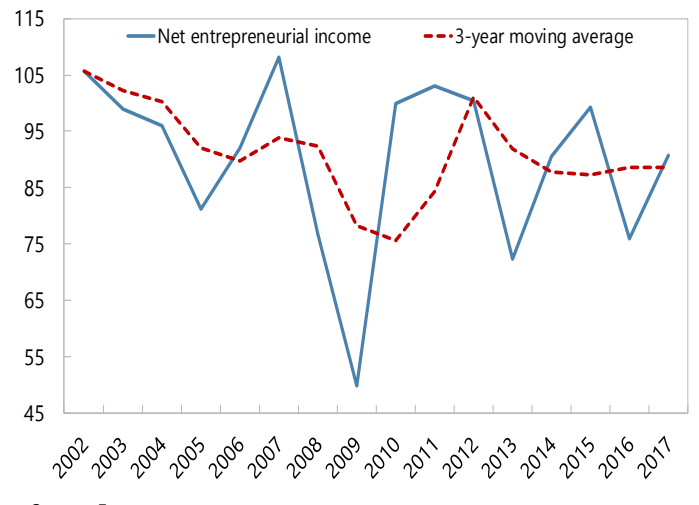

Source: Eurostat.
Increasing income differentials with other sectors led to a rural exodus...

Evolution of the Rural and Agricultural Population 1/

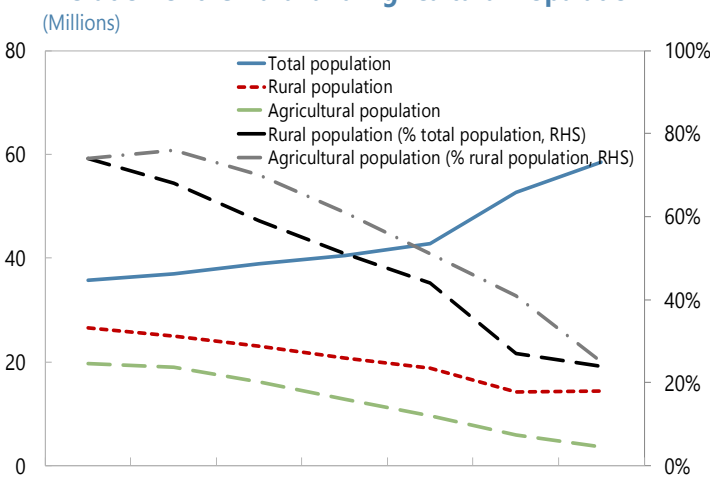

$\begin{array}{lllllll}1851 & 1876 & 1901 & 1926 & 1954 & 1975 & 1999\end{array}$

1 / Working, not working, males and females

Source: Pierre Dauce', 2015, Agriculture et monde agricole, Le Documentation Francaise.

However, agriculture and agri-food still generate important spillovers onto other sectors.

Sales and Purchases of Agriculture and Agri-food

to Major Sectors of Activity in $\mathbf{2 0 1 2}$

(Billions of euros)

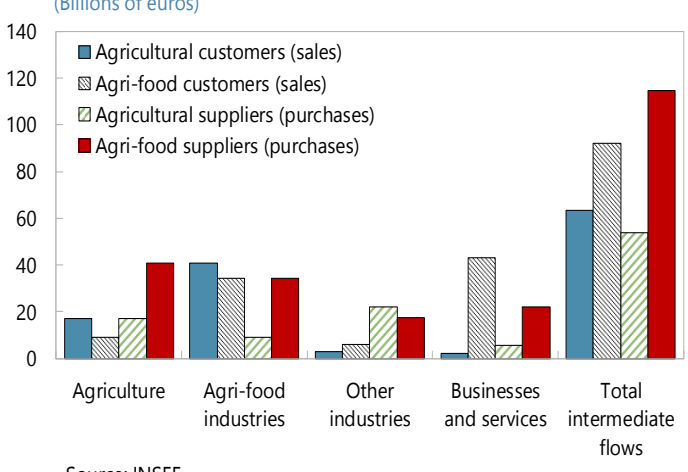

Source: INSEE.

...although this masks a strong dispersion across farms by different sizes.

Pre-Tax Non-Salary Earnings for Annual Working Unit (Thousands of euros/annual working unit)

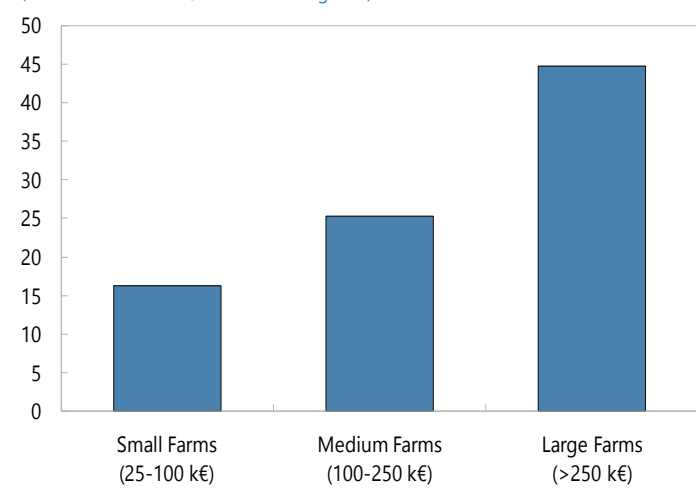

Sources: Agreste, RICA France , 2017.

\section{CInternational Monetary Fund. Not for Redistribution}


5. Today agriculture remains a key source of trade surpluses and of intermediate exchanges with all sectors of the economy, despite the sector's declining contributions to GDP and employment.

From around 1970, France has become a net exporter of agri-food products (raw and processed), and today it is the 6th largest agri-food exporter in the world, with the agri-food sector now accounting for France's second-largest trade surplus (after transport equipment and chemical products and

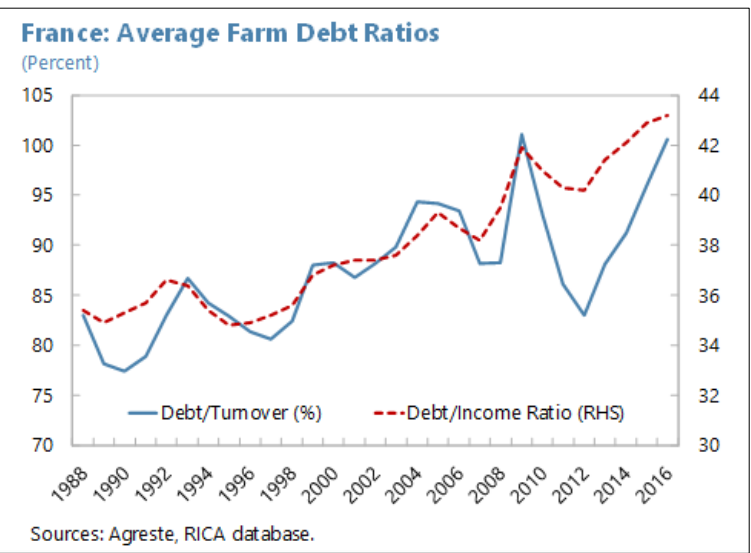
pharmaceuticals, Figure 2). In addition, there are substantial flows from agriculture and the agro-food sector to other business sectors, beyond the important exchanges that take place between agriculture and agro-food industries, and within each branch (Figure 1). These links mean that any increase in the demand for raw and transformed agricultural goods has positive impacts on the activity of other economic sectors, spurring overall economic growth.

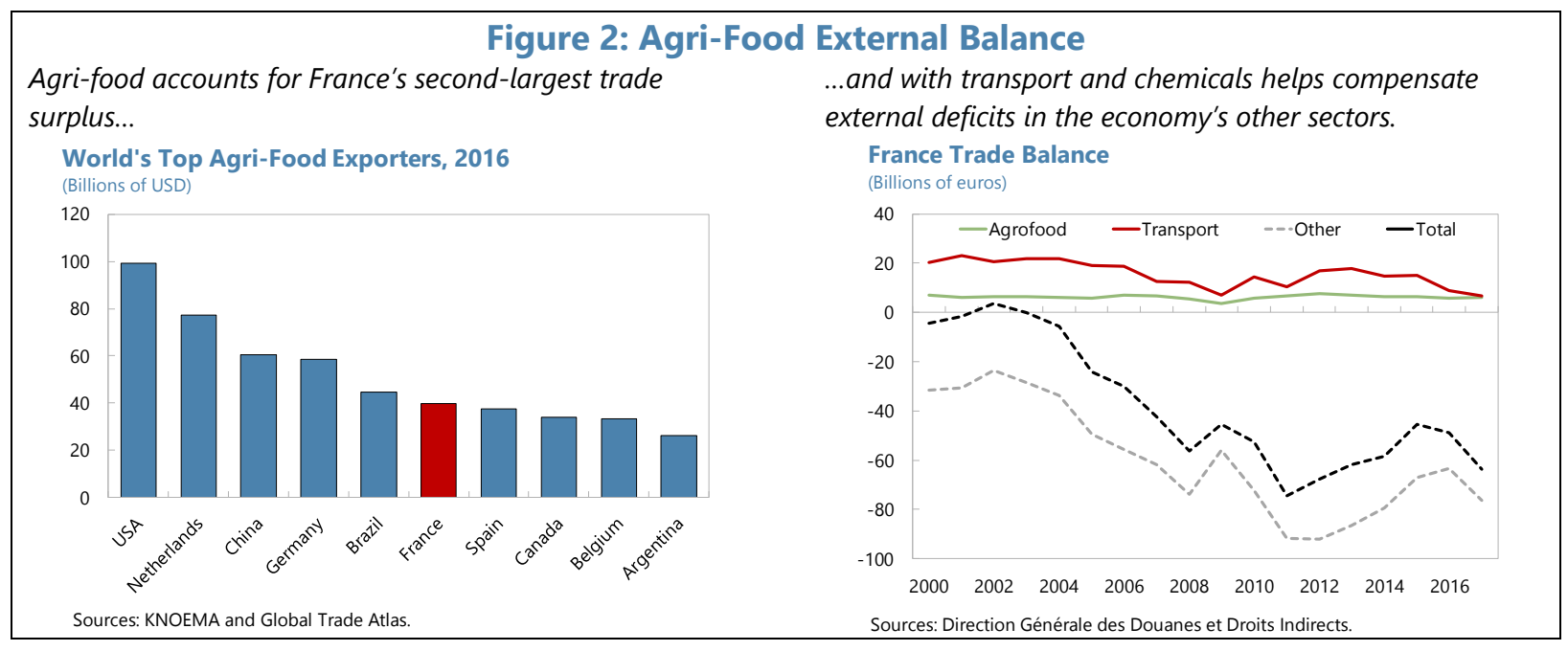

\section{KEY CHARACTERISTICS OF THE FRENCH AGRI-FOOD SECTOR}

6. France leads Europe in agriculture. France covers an area of about 0.6 million $\mathrm{km}^{2}$ and has the largest agricultural area in the EU-28 (28 million ha), accounting for 16 percent of total EU utilized agricultural area (UAA), producing about a fifth of all EU agricultural production (18 percent in 2016), ahead of Germany, Italy and Spain (at 14, 12 and 12 percent, respectively), and employing 8 percent of all EU agricultural labor. It holds the largest EU share of cereal and oleo-proteins cultivated land, and it is the EU's main producer of cereals, beef and veal — rearing almost a quarter of all EU bovine population — while ranking second in the production of milk (Figure 3). 
7. The French agricultural sector is highly diverse - from temperate crops and livestock in the north and center to "Mediterranean" products in the south and boasts some of the most productive crop areas (e.g. wheat) in the EU, as well as many areas with natural constraints.

8. From a market-structure point of view, France has more large farms and employs less people in comparison with the rest of the EU-28. Specifically, in France 21 percent of holdings have more than 100 hectares compared to 3.1 percent on average in the EU-28, and while the primary sector accounts for 1.7 percent of the country's economy (total GVA) compared to 1.6 percent (EU-28), agricultural employment only accounts for 2.7 percent of total employment compared to 4.5 percent in the EU-28. And within this a larger share is represented by young farmers -8.8 percent are under 35 years old (versus 5.9 percent in the EU-28), while only 12.4 percent are older than 64 (30.6 percent in the EU-28). ${ }^{4}$

9. The production system is dominated by conventional agriculture, also known as industrial agriculture. More precisely, based on Insee and Eurostat data, 90 percent of French arable land is farmed using conventional methods, which implies the intensive use of synthetic chemical fertilizers, pesticides, herbicides and other continual inputs, the use of (imported) genetically-modified crops to feed livestock, ${ }^{5}$ heavy irrigation, intensive tillage, and concentrated monoculture production. The remaining 10 percent of arable land is farmed using organic or integrated methods ( 3 and 7 percent, respectively).

\section{While still small, however,} France's non-conventional

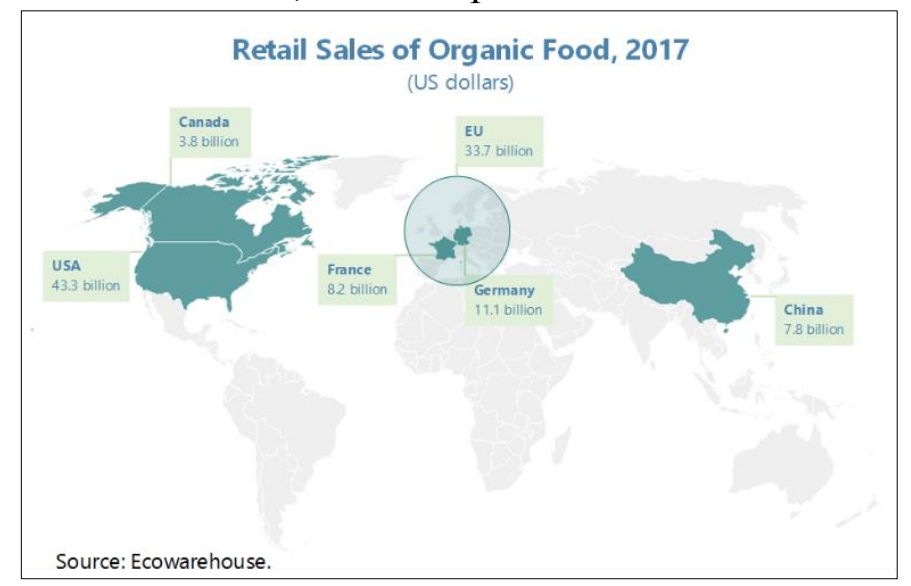
production, especially organic, is expanding fast. France is the third-largest organic food retailer in the world, with 7 percent of the global market in 2017, behind the United States (more than 40 percent) and Germany (11 percent) but just ahead of China, Canada and other EU countries. France's organically-farmed land-now equal to 7 percent of all French utilized agricultural area and 13 percent of all EU organic land - is expanding at a fast rate $(+70$ percent between 2012-2017) to keep up supply at par with accelerating demand (Figure 3).

\footnotetext{
${ }^{4}$ Eurostat Database, 2018. See also Rovný, 2016; and Eurostat Farm Structure Survey (FFS), 2013.

${ }^{5}$ The production and sale of certain genetically modified organisms (GMOs) are legal in France but are subject to very restrictive rules. French legislation regarding GMOs falls within the broader framework of European regulation, but France has supplementary national rules that provide additional restrictions. These rules are particularly focused on th potential release of GMOs in the environment, and on labeling requirements for GM products. French legislation also requires that the location of GM crops be public information and establishes strict liability rules regarding the possible release of GM crops into non-GM fields. Because of both public hostility to GMOs and these legal restrictions, there are currently no GM crops grown in France, even though France imports substantial amounts of GMOs from abroad.
} 


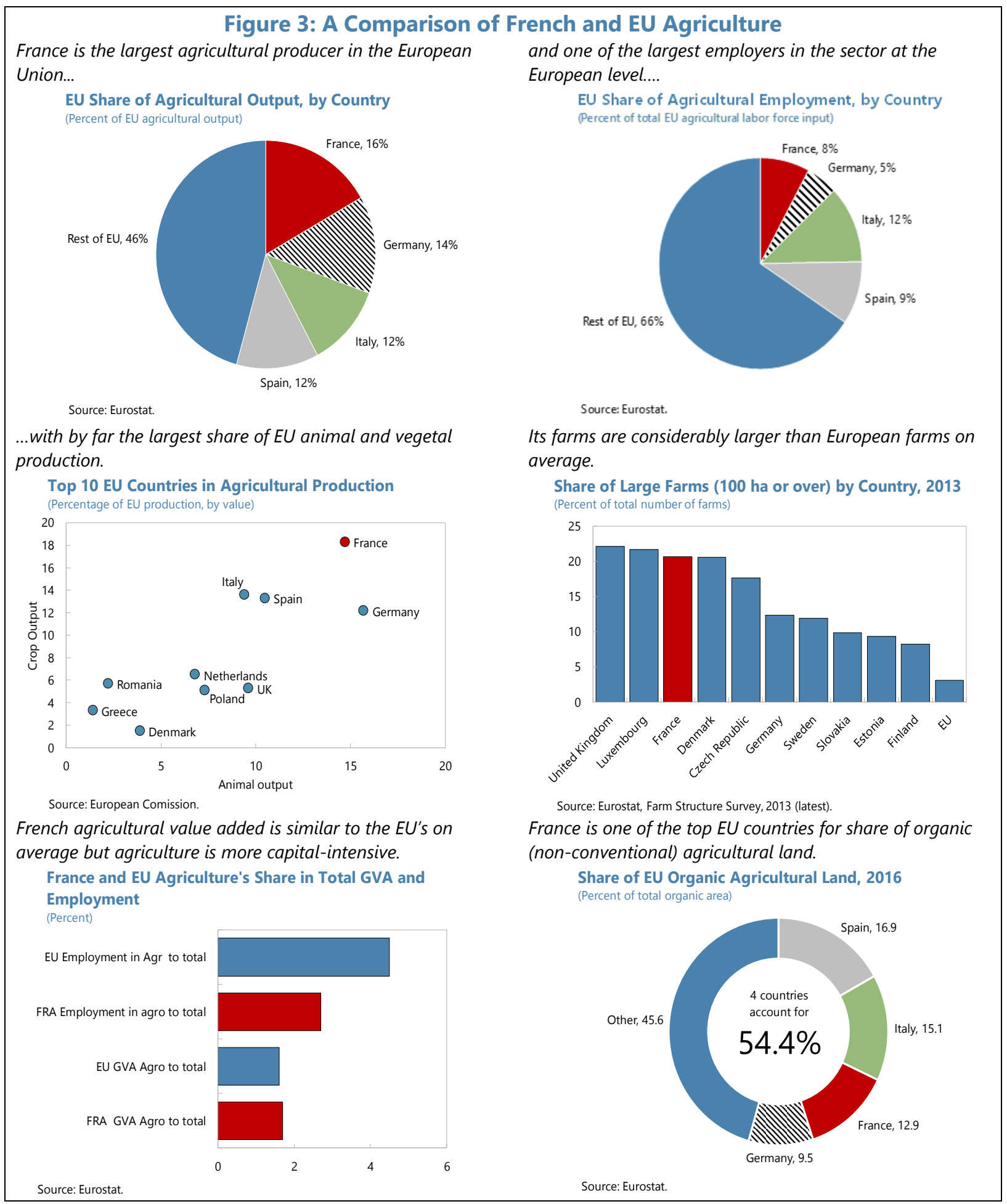

CInternational Monetary Fund. Not for Redistribution 


\section{FRENCH AGRI-FOOD SECTOR'S EXTERNALITIES}

11. France's overall environmental record has improved substantially since the 1990s, with greenhouse gas emissions (GHG) falling by about 15 percent since then (Figure 4). These improvements reflect primarily a shift in the energy sector, where production from traditional fossil-fuel power plants was almost completely substituted with production from nuclear power plants (which emit no carbon dioxide directly. Nuclear plants now provide 72 percent of all electricity in France, ${ }^{6}$ from about 1 percent forty years ago ${ }^{7}$ ). As a result, France's per capita overall GHG emissions are low when compared to other advanced and large emerging market countries.

12. But environmental progress in the agri-food sector has been more modest. Between 1990 and 2012, agricultural emissions in France fell but by less than other sectors ( 9.6 percent). ${ }^{8}$ The reduction can be explained by a decline in the use of chemical fertilizers, the reduction in utilized agricultural land and cattle numbers (primarily as a result of more intensive dairy farming), and the drop in energy consumption since 2004 (MAAF CSSF, 2014. See Figure 4).

\section{Reflecting current production volumes and methods, and its huge livestock, the sector's environmental externalities remain large both in an absolute and relative sense.} Given the sheer size of land farmed, the dominance of conventional farming implies that France tops the EU for its use of fertilizers and pesticides and it employs these in amounts that are greatly above the EU-28 average (Figure 4). Prevalent production methods combined with the large number of livestock also mean that France's GHG emissions from agriculture alone are the highest in the EU-28 in absolute terms and in per capita and/or as a share of the world largest agriculture-related GHG emitters, e.g. China and the United States (Figure 4). ${ }^{9}$ When emissions from agriculture are combined with those from the food industry, including waste management, and with those from the production of agricultural input, such as the manufacturing of nitrogen fertilizers, phytosanitary products, imported food feeds for livestock, the direct and indirect effects on emissions total over a third (36 percent) of all France's GHG emissions, approaching those of the transportation and construction sectors combined. ${ }^{10}$

6 "PRIS - Country Details". See: pris.iaea.org and http://www.world-nuclear.org/information-library/facts-andfigures/nuclear-generation-by-country.aspx\#.UkrawYakrOM.

${ }^{7}$ See https://www.iea.org/Sankey/index.html\#?c=France\&s=Balance.

${ }^{8}$ MEED, Ominea Database, 2018. Data on sub-sectoral GHG emissions by activity exists up to 2016 but it is not yet accessible in aggregated form beyond 2012.

${ }^{9}$ French $\mathrm{CO} 2$-equivalent greenhouse gas emissions (GHG) from agriculture and land management alone (notably from soil carbon impact, methane and nitrous oxide emissions from the industrial production and widespread use of inorganic fertilizers, as well as from soil denitrification, enteric fermentation of cattle, and manure decomposition) are estimated at around 20 percent of France's total GHG emissions, making it the third emitter in the country. This calculation comes from official inventories, which are based on the scientific literature and rigorous methods: see INRA, 2013, based on estimates by the Intergovernmental Panel on Climate Change and (IPCC) and of the Centre Interprofessionel Technique d'Etudes de la Pollution Atmosphérique (CITEPA). Nonetheless, it is a complex exercise (see Box 1, page 2 of MAAF CCSF, 2014)) and subject to some significant uncertainties. There are also numerous debates and in some cases controversy about these methods, which are regularly reviewed and improved in line with scientific advances.

${ }^{10}$ France (mainland France) + DOM-TOM emitted 496 million tonnes equivalent CO2 (MTEqCO2) in 2010 (taking into account the $33 \mathrm{MTEqCO} 2$ fixed by the "carbon sinks" of agricultural soils and forests). With more than $170 \mathrm{MtCO}$, agriculture and food-from the plot to the treatment of food waste-are responsible for 36 percent of these emissions. See Solagro, 2016, Afterres2050. 


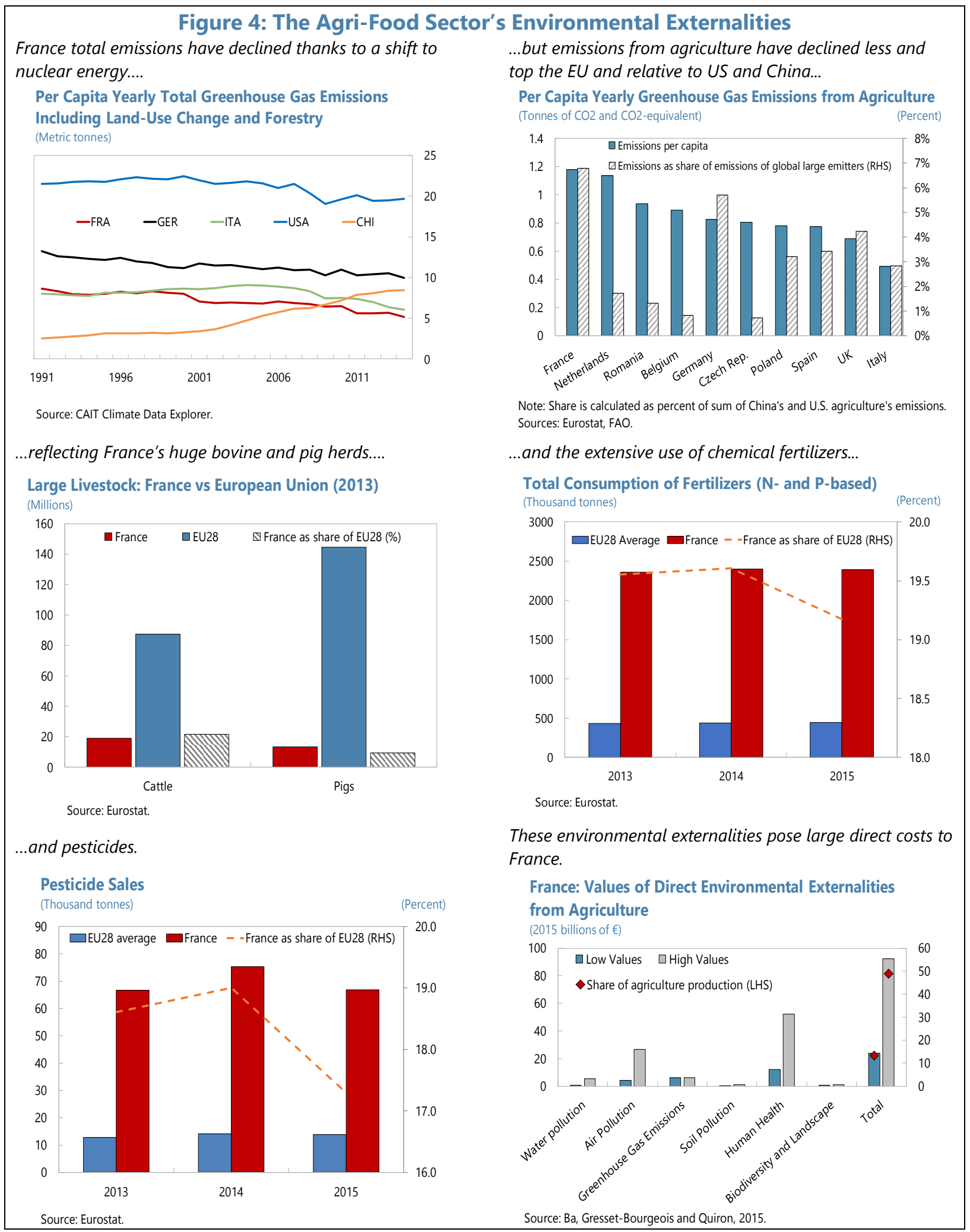

CInternational Monetary Fund. Not for Redistribution 
14. Other large supply-side externalities include air, soil and water pollution, and loss of biodiversity. ${ }^{11}$ The overall environmental economic damage generated by agriculture, considering water pollution, air pollution, emissions of greenhouse gases, soil pollution, the impact on human health of pesticides, and impacts on biodiversity and landscapes is potentially large: estimates obtained homogenizing selected relevant economic quantification studies of such externalities for France put them between 14 and 55 billion euros per year (Ba, Gresset-Bourgeois and Quiron, 2015). These figures are not negligible compared to the value of agricultural production (around 68 billion euros), and yearly subsidies to agriculture and agricultural products (around 11 billion euros) (Figure 4).

\section{Current production methods across} the agri-food chain also generate considerable food waste and loss. Every year, 10 million tons of food, one fifth of the national production, ${ }^{12}$ is wasted or lost (see ADEME, 2016, Fusion, 2016) $)^{13}$ - the equivalent of nine meals a day for the 12 percent (4 million) of French people who are food insecure. These losses - the cost of which is estimated at $€ 16$ billion euros per year in France, have a climate impact of more than 15 million tons of $\mathrm{CO} 2$ equivalent (out of France's total of nearly 480 million tons per year).

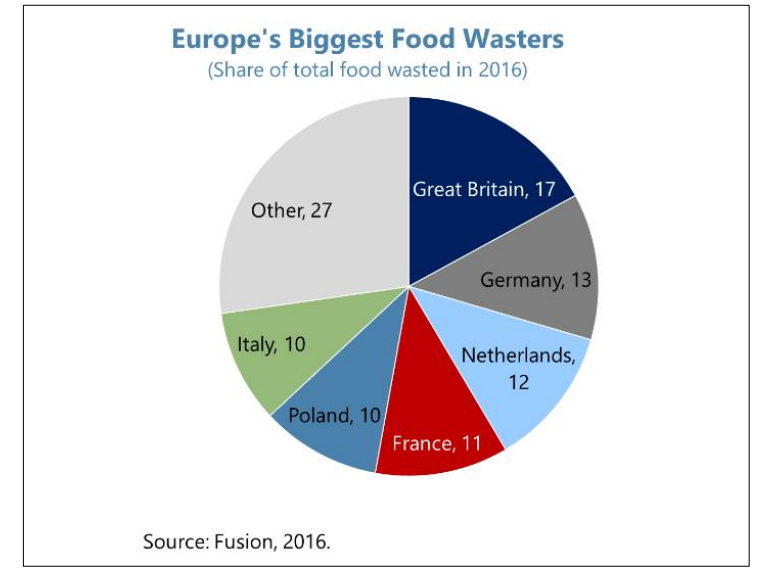

16. On the demand side, conventional agriculture in France and more globally has contributed to spur a change in diets which bears important individual and collective public health risks. ${ }^{14}$ Reflecting a combination of lower food prices from higher agricultural productivity, higher incomes, urbanization, faster-paced living, and the concentration of food retailers into few large supermarket chains, the modern French diet has become substantially different from what it was in the past century (ADEME, 2016). Compared with the 1970s, and

\footnotetext{
${ }^{11}$ France is host approximately to an estimated 55 thousand species of animals and plants. Many of these species are endemic to Europe and are found nowhere else in the world. Approximately $1 / 3$ of the species assessed by the European Red List of Species are present in France-representing more than 3 percent of the species in the world. Among these, about 10 percent are considered "threatened" and a similar fraction are "near threatened" at the European level, and one species is "extinct in the wild" (IUCN EURedList, 2013).

${ }^{12}$ This average masks even higher levels in some sectors: 21 percent for poultry, or even 30 percent for products from fishing and aquaculture (ADEME, 2016).

${ }^{13}$ See "Pertes et gaspillages alimentaires : l'état des lieux et sa gestion aux différentes étapes de la chaîne alimentaire", Agence de l'environnement et de la maîtrise de l'énergie (ADEME), May 2016 (https://lc.cx/gPfd).

${ }^{14}$ It could be argued that the extent according to which the health effects from unhealthy eating might be an external cost depends on the extent of consumer awareness about the long-term health risks, in line with the debate about this in the tobacco tax literature (see Viscusi, 1998; and Gruber and Koszegi, 2001). This argument is less strong however when people with unhealthy habits people impose net external costs on thirdparty medical services either in the short or medium run.
} 
following the globalization of food habits, French people today consume considerable more calories and meat. ${ }^{15}$ And while they consume the same amount or more fruit than other advanced peers, they consume less vegetables, on average. (Figure 5). ${ }^{16}$

\section{In per capita terms, France has become the first consumer of fat in the world.}

The FAO Food Balance Sheet Dataset ranks France's per capita daily fat intake 1 st in the world, the protein daily intake at the 5th place in the world, and the per capita caloric intake at the 12th highest level in the world — values all considerably above the healthy diet-recommended WHO values in per capita terms (FAO, 2017; and WHO, 2017). These findings are confirmed by the Agence Nationale de Sécurité Sanitaire de l'Alimentation, de l'Environnement et du Travail (ANSES) latest examination of French eating habits in 2014-15 by socio-demographic group (ANSES, 2017), ${ }^{17}$ which reports that both young and older French consume too many calories, too many proteins, too much salt, and too little fiber, partly reflecting the fact that, today $2 / 3$ and $1 / 2$ of all food intake by French children and adults, respectively, is processed industrially — a larger share than in 2006-7 (see INCA2). ${ }^{18}$

\section{Reflecting this, the number of French overweight and obese people has increased} sharply over time, as has the prevalence of dietary-risks-related diseases. France now has one of the highest rates of adult overweight people in Western Europe (with about 2 in 3 French now overweight), and 1 in 5 French people are now obese. Like in other advanced countries, the increase in overweight and obese population has been associated with an upward trend in non-communicable diseases (NCDs), notably cardiovascular diseases (CVDs), diabetes Type II and cancer, to which unbalanced diets and excess weight are demonstrated to be a key contributor (WHO, 2004; EU, 2017). And despite the fact that France still displays a comparatively lower rate of premature deaths from CVDs that its European peers (the so-called "French paradox"), ${ }^{19}$ its rate of age-standardized ${ }^{20}$ prevalence of CVDs is higher than in peers, indicating that the shift in diets, especially among younger

\footnotetext{
${ }^{15}$ While the share of meat consumption in the French food consumption basket has fallen from around 26 percent in 1960 to 20.4 percent in 2014, meat consumption has grown in absolute terms alongside the growth of food intake and calories and it is considerably larger than in the past. See Larochette, and Sanchez-Gonzalez (2015).

${ }^{16}$ See data from the European Cardiovascular Disease Statistics, 2017.

${ }^{17}$ Anses, 2017, “INCA3: Étude individuelle nationale des consommations alimentaires 3”, 2017.

${ }^{18}$ See Gazan et al. (2016).

${ }^{19}$ Specifically, on 2014 data, France displayed about 3 percent of ischemic heart diseases vs. 7 percent in the EU on average; 3.5 percent from strokes vs. 6 percent; and about 6 percent from other CVDs vs. 9.2 percent on average in the EU. This phenomenon is known as the "French paradox", given French's notoriously rich in saturated fats diet that should constitute a high (not lower) dietary risk for CVDs. This paradox has been attributed to both underreporting of CVD incidence by the French authorities as well as to the existence of delay in serum cholesterol concentrations increasing and a subsequent increase in ischemic heart disease mortality, which would explain why the current rate of mortality from coronary heart disease is more likely to be linked to past levels of serum cholesterol and fat consumption than to current serum cholesterol levels and patterns of fat consumption (Law and Wald, 1999).

${ }^{20}$ Age standardization, is a technique used to allow populations to be compared when the age profiles of the populations are quite different. Age-standardized data like the ones used here from the WHO European Health For All Database show a more accurate and slightly different (worse) picture for France when compared to other countries using non-age-standardized data.
} 
cohorts of the population, may translate into a step increase in CVD (morbidity and) mortality as these cohorts age, unless behavioral risks - among which primarily diets - are addressed.

19. These trends bear huge macroeconomic costs, beyond those for the individual and society. The total annual expenditure (health and non-health, where the latter includes production losses due to mortality and morbidity alike, and informal care) from NCDs can be estimated for 2015 at around 6 percent of GDP (Figure 5). ${ }^{21}$ With overall public spending health in France at 8.2 percent of GDP in 2016, this health externality is significant considering that more than 80 percent of CVDs, 90 percent of diabetes Type II and obesity, and 30 percent of cancers are preventable by controlling behavioral risk factors, mainly through a balanced diet — controlling for other risk factors like smoking and lack of physical activity (WHO, 2004; EU 2017).

\footnotetext{
${ }^{21}$ Considering only the cost of non-communicable diseases to the health care systems grossly underestimates the true cost of these diseases. Production losses from death and illness in those of working age and from the informal care of people with the disease contribute greatly to the overall financial burden. Informal care costs are equivalent to the opportunity cost of unpaid care. This opportunity cost is a measure of the amount of money that carers forgo to provide unpaid care for their spouses, friends or relatives suffering from CVD, cancer or diabetes. Estimates based on various official sources of non-health care costs are included in the calculation reported above. In 2015, production losses due to mortality and morbidity associated with CVD cost the EU $€ 54$ billion, with 58 percent of this cost due to death (32 billion euros) and 42 percent due to illness ( 23 billion euros) in those of working age. (for a detail explanation of how mortality and morbidity costs are estimated see European Cardiovascular Statistics Network, 2017).
} 
Figure 5: The Agri-Food Sector's Public Health Externalities

French consume more calories than peers and considerably more what is recommended.

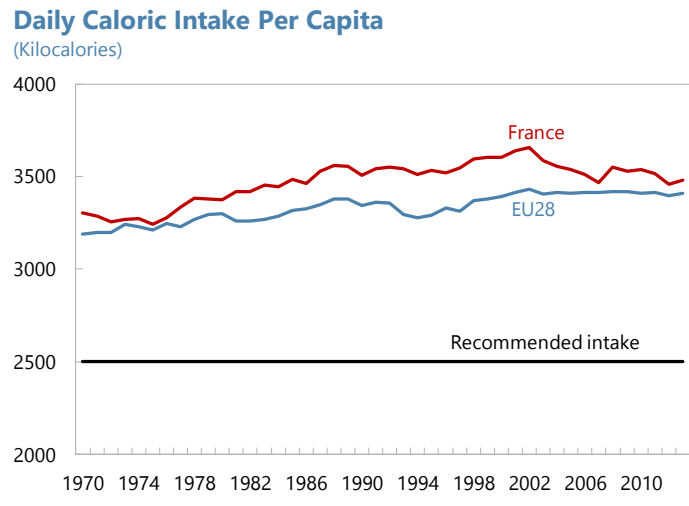

Source: WHO Food Balance Sheets.

...so that one in three French is now overweight and over 1 in 5 obese.

Obesity and Overweight Rates in the European Union, 2018 (Percent, 18+, age-standardized)

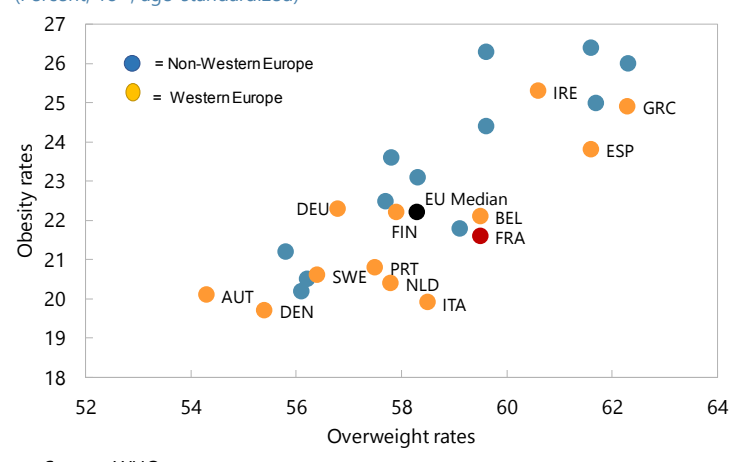

Source: WHO

CVDs's care is expensive, and France spends more on it than peers, per capita.

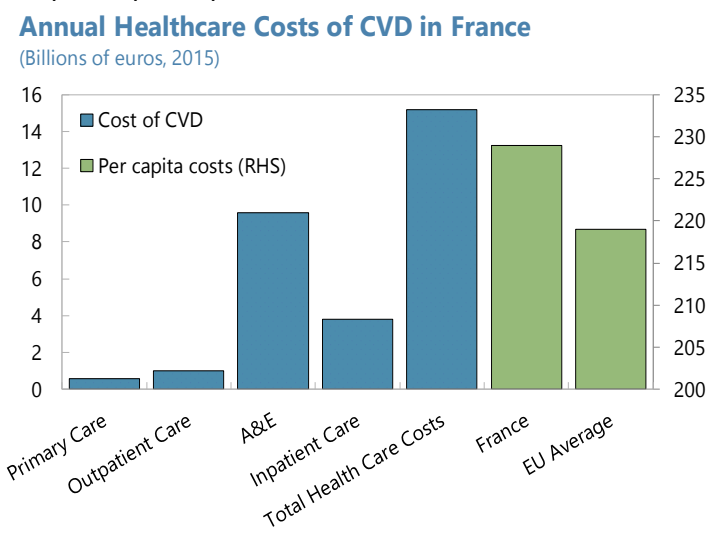

Source: European Cardiovascular Disease Statistics 2017
The French also consume more calories from animal and less from vegetal foods than European peers...
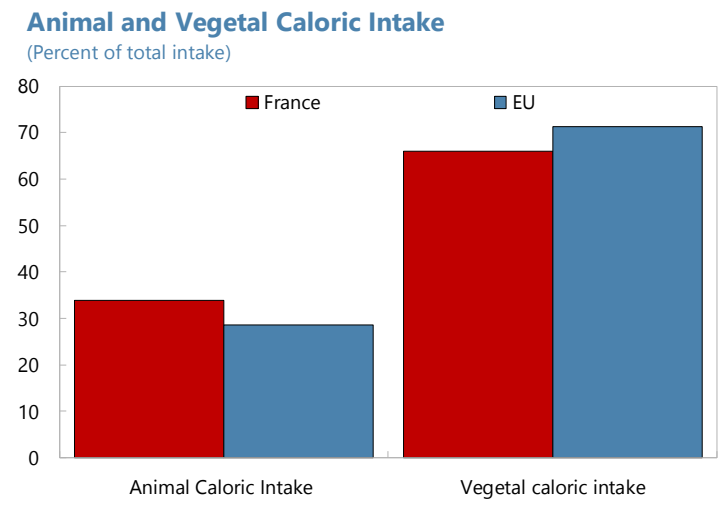

Source: WHO Food Balance Sheets.

...contributing to a high prevalence of cardiovascular diseases.

Age-standardized Prevalent CVD Cases

(Per 100,000 of cardiovascular diseases)

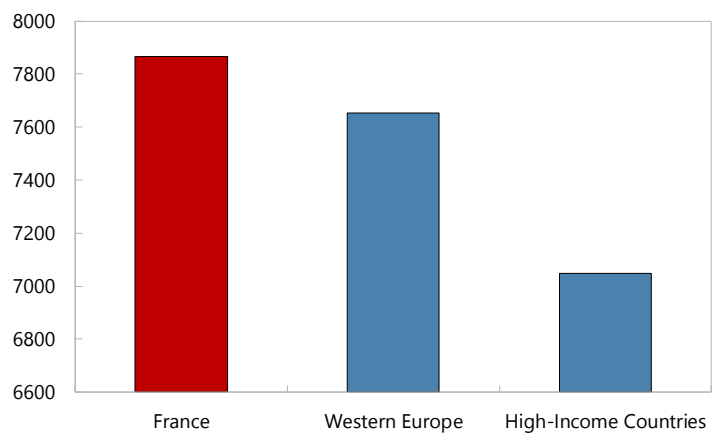
Source: Global Burden of Disease Study, 2016.

Overall, dietary-risks-related diseases take a huge economic toll every year on the French economy.

Total Annual Costs on Non-Communicable Diseases (NCD), 2015

(Percent of GDP)

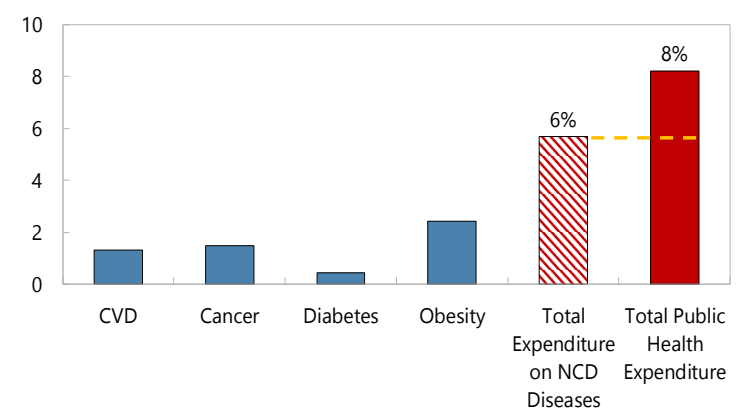

Sources: Cardiovascular Diseases Statistics; Inca; Arc; McKinsey Institute, Cabinet IMS Health, Care Lab and IMF Staff Calculations. 
20. Conventional agri-food production methods pose additional risks and costs for public health. Of all antibiotics sold in France about $3 / 4$ are sold for use in animal agriculture as conventional animal agriculture uses these for non-therapeutic reasons, ${ }^{22}$ notably to prevent infections in animals constrained to live large part of their lives in closed quarters (Martin, Totthatil and Newman, 2015; WHO, 2015). This practice, common in all countries practicing conventional animal agriculture, together with the use of antibiotics as growth promoters in feed, is indicated as the key contributor to the emergence of antibiotic-resistant strains of bacteria that make treating human (and animal) illness more difficult, and which is estimated to imply now and in the future enormous economic losses both in advanced and in developing countries (O'Neill, 2015; and EFSA, 2015). ${ }^{23}$ In 2010, together with the Netherlands, France was the largest consumer of antibiotics in agriculture in the EU. Since then, in 2012 France has launched a plan to reduce the use of antibiotics in agriculture by $1 / 4$ in 5 years - the ÉcoAntibio Plan 2012-2016 - followed by a second plan for the period 2017-2021 (ÉcoAntibio 2 Plan). ${ }^{24}$ While the target for the original EcoAntibio Plan has nearly been reached, with a drop of about 20 percent in the exposure of animals to antibiotics (all families) between 2012-2015 inclusive, this decrease varies according to the animal sectors, with a very significant decrease in pigs, but more measured in cattle, and 800 tons of antibiotics still sold in 2013. As a result, the risk of morbidity from drug-resistant diseases associated to antibiotic veterinary use in agriculture has diminished considerably but has not been eliminated - around 150,000 French people developed drug-resistant diseases in 2015, leading, in that year alone, to over 12,000 deaths (Carlet and Le Coz, 2015). ${ }^{25}$ Reflecting this, EcoAntibio 2 Plan will try to evaluate the impacts of the first plan, maintaining the same dynamics and pursuing the measures already underway focusing more on incentivization than regulatory measures.

\section{CHANGING THE FRENCH AGRI-FOOD SYSTEM: A WIN-WIN-WIN PROPOSITION}

\section{A paradigm shift in French agri-food system can help France on three fronts.}

22. On the environmental front, both at the national and at the international level, France has committed to transform its economy so as to drastically reduce GHG emissions over the near to medium term. In November 2015, following the Paris Climate

\footnotetext{
22 Antibiotics in feed are also used widely as growth promoters in conventional animal agriculture, but this practice was banned in the EU in 2006. See Regulation 1831/2003/EC on additives for use in animal nutrition, replacing Directive 70/524/EEC on additives in feeding-stuffs.

23 The O'Neill Report on Global Antimicrobial Resistance (2016) estimates yearly losses per country of about 3 percent of GDP until 2050 if current antimicrobial resistance trends are to continue. See also, EFSA (2015).

24 The plan aimed at reducing the exposure of animals to antibiotics by 25 percent in 5 years, with a particular attention to the use of critically important antibiotics in veterinary and human medicine (such as third and fourth generation cephalosporins and fluoroquinolones). The 25 percent reduction target was chosen to match the 25 percent objective set by the French Ministry of Health to reduce the use of antibiotics aimed at humans, which itself was chosen because the use of antibiotics by people in France is about $25 \%$ higher than the European average. The Ministry of Health hopes that 25 percent reduction objective will bring the France down to the European average.

${ }^{25}$ Carlet, J. and Le Coz, P., 2015. "Together let's save antibiotics: report for the special working group for keeping antibiotics effective". http://social sante.gouv.fr/IMG/pdf/rapport_antibiotiques.pdf; June 2015.
} 
Agreement, France has launched a National Low Carbon Strategy (Stratégie National

Bas-Carbone, 'SNBC') — an ambitious set of climate and energy targets within the framework of the commitments made by the European Union. Under the SNBC, France committed to modify production across its non-agro economic sectors in order to reduce its GHG emissions by 75 percent by 2050 compared to 1990 - an objective which is referred to as the "factor 4 objective" and reduce them by 2028 by a cumulative 27 percent compared to 2013 via a series of 'carbon budgets'. The SNBC was followed in 2017 by an even more ambitious Climate Plan, aiming to achieve carbon neutrality by 2050 . As an EU Member State, France has also committed to halting biodiversity loss by 2020, an ambitious goal to reconcile with the continuous observed modification to natural systems, agriculture and aquiculture, and their expansion and intensification and relatedly the over-extraction of water. All these commitments reflect the notion that, if unaddressed, climate change and environmental degradation will have adverse, permanent effects on the French economy (OECD, 2015; I4CE, 2015). ${ }^{26}$

\section{Making the agri-food system environmentally-sustainable is possible and} essential to achieve France's environmental targets. Considered the significant contribution of agriculture to France's GHG total emissions (around 20 percent of total man-made GHG emissions in 2014 versus 9-10 percent in the EU28) ${ }^{27}$, France's strategy in the pursuit of its carbon footprint objectives involves a considerable reduction in GHG emissions coming from improvements in the agriculture sector's carbon footprint. More specifically, the targets set for the agriculture call for a halving of the sector's emissions by 2050 ("factor 2 objective"). These are minimum goals. Agriculture, on the other hand, is also one of the most severely affected by climate change, to which it must inevitably adapt. ${ }^{28}$

\section{Several recent studies have explored more or less ambitious GHG mitigation scenarios for French agriculture looking ahead to either 2030 or 2050 (Box 2 discusses} the prominent six ones). Beyond the uncertainties associated with any quantification exercise, all studies indicate that without additional efforts compared with the current situation, the reduction of emissions will be limited (less than 10 percent by 2030). ${ }^{29}$ By

\footnotetext{
${ }^{26}$ See also Ministère de la Transition Écologique et Solidale, (2018) (http://www.statistiques.developpementdurable.gouv.fr/lessentiel/ar/2533/0/impacts-potentiels-changement-climatique-lhorizon-2050.html).

${ }^{27}$ See Ministère de l'Agriculture, de l'Agroalimentare ed de la Foret (2014), "French Agriculture and the challenge of climate change: what are the prospects for mitigating its greenhouse gas emissions by the French Centre for Studies and Strategic Foresight (Centre d'Études et de Prospective - CEP) No. 73, October 2014.

28 See the Agriculture and Forestry planning exercise "Climat : vers des stratégies d'adaptation" carried out in 2013 by the French Centre for Studies and Strategic Foresight (Centre d'Études et de Prospective - CEP) http://agriculture.gouv.fr/Seminaire-de-restitutionAFCLIM.

${ }^{29}$ It should be noted that this technical potential is heavily dependent on the calculation methods used (emissions coefficients and scope), which makes this apparently technical subject a major topic for the coming years.
} 
improving the "carbon efficiency" of agricultural practices and making use of technical levers (e.g. nitrogen management), emissions could be reduced by around 10-20 percent by 2030. To achieve more than a 20 percent reduction by 2030 and get close to the government's "factor 2" target by 2050, these studies reveal, it will be necessary to focus on scenarios with a shift from current production and consumption systems. As a result, the most ambitious scenarios ( -50 to -60 percent) are based on a fairly radical change of agriculture and food (bumping up considerably organic versus conventional production, reducing food waste and loss, cattle and dairy cattle numbers, consumption of animal proteins, etc.). Specifically, scenarios based on model simulations in the Afterres' exercise conducted in 2013 and exploring the environmental impact of alternative changes to production systems and land use in French agriculture indicate that, by 2050, it is possible to reduce by a factor of 2-3 both inputs and negative externalities, including GHG emissions, ammonia, mineral nitrogen, energy and phytosanitary products - while also reducing water withdrawal despite a projected increase in the surface of irrigated agricultural land. (See Box 1 and Figure 6).

\section{On the direct macroeconomic front, a well-designed transition to sustainable} agri-food system promises several tangible gains. According to model simulations in Afterres, the same modifications capable of delivering on France's carbon reduction targets for the sector are likely to deliver an increase in agricultural production and value-added, more numerous farm and food industry jobs, and substantial trade gains relative to a business-as-usual scenario (see Box 1 and Figure 6). 


\section{Box 1: Results from Models Simulating a Paradigm Shift in French Agriculture}

Numerous models have been used to explore ways to modify agricultural methods, land use, and diets in the pursuit of France 2030-2050 environmental goals. A 2014 meta-analytical paper by the French Ministry of Agriculture, Agri-Food and Forestry-MAAF-CSSF compares the methods and approaches of the key studies in detail. These include: (i) the 2013 MAAF CSSF "Agriculture énergie 2030" study; (ii) the 2013 INRAMEDDE-ADEME "How can French agriculture contribute to reducing GHG" study; (iii) the 2012 Solagro-ISLOréade-Brèche "Agriculture et facteur 4" study commissioned by MAAF and ADEME; (iv) the 2013 and 2016 Afterres2050 studies by Solagro; (v) the 2013 ADEME "Visions Energie-Climat 2030-2050"; and (vi) 2011 Perthuis Committee Report "Trajectoire 2020-2050 vers une économie sobre en carbone".

Among these studies, the analysis in Afterres 2050 offers the most advanced and comprehensive study of how to reconfigure in practice agro-food production and reorient consumption to deliver the government's "factor 2" de-carbonization target for agriculture by 2050 (while other consider other decarbonization targets or assume unchanged production and systems) and has thus been a key input in the course of the consultative debate during the government-organized Food General Assembly in the preparation of the 2018 Agriculture and Food Bill proposal.

The baseline simulation assumes a gradual modification to the use of land and farming methods and a gradual, parallel shift in diets toward WHO-recommendations. In particular, it assumes: (i) a gradual elimination between 2010 and 2050 of all synthetic inputs to production and their total replacement with agroecological methods, notably organic (50 pc) and integrated (50 pc) agricultural methods; (ii) a full shift over the same time period in the sector's use of energy to renewables; (iii) a reduction in the herd of cattle (against unchanged pasture land) accompanied by an expansion of smaller-sized livestock herds, notably ovine; as well as by (iv) an expansion of agro-forestry production. The simulation couples the assumptions about the shift in agriculture with the assumption of a shift in diets based on a modest reduction in per capita caloric intake and a reduction in the consumption of meat, dairy products and sugar, accompanied by an increase in the consumption of fresh fruit and vegetables, pulses, cereals and nuts (see Figure 6).

Results indicate that such transition could deliver several tangible macroeconomic gains. Specifically, it could: (i) quadruple agricultural non-food production, while maintaining current levels of primary production; (ii) raise the sector's value added by 10 percent; (iii) avert the projected deterioration of the sector's trade balance under the current-policy scenario by increasing cereal exports for human consumption to the Mediterranean region and the Middle East, halving exports of fodder crops to Europe and eliminating imports of soya and France's trade deficit of in forest products; (iv) increase agricultural jobs by 7-11 percent at current productivity growth levels, and by more for lower future productivity levels; (v) double the stock of agro-ecological infrastructure, with multiplicative growth effects on the rest of the economy. (see Figure 6).

The simulations indicate French environmental targets for agriculture would be attainable following the prescribed transition (see Figure 6). 
Figure 6. Afterres2050: A Workable Agri-Food Reform Scenario

Hitting public health and environmental targets requires more organic farming, less waste and less consumption of animal protein...

Alternative 2050 Scenarios: Food and Production Methods (Percent of total)

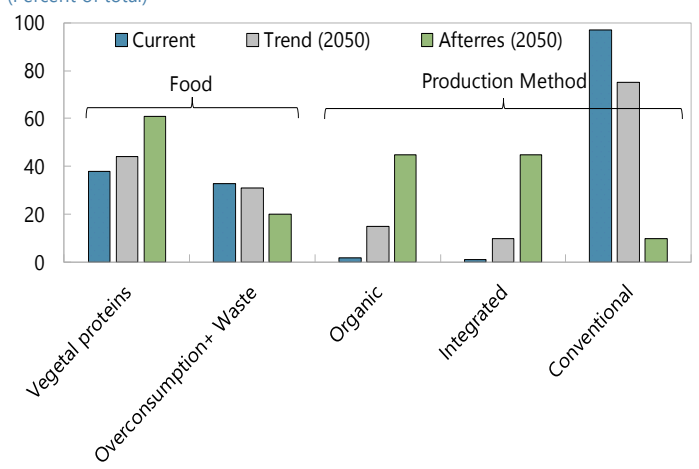

Source: Afterres2050, Solagro (2013).

More cattle would have to be on pasture, pigs would have to be raised sustainably, and less hens should be in cages.

Alternative 2050 Scenarios: Animal Rearing Methods

(Percent of total; Milk at thousand liters per year)

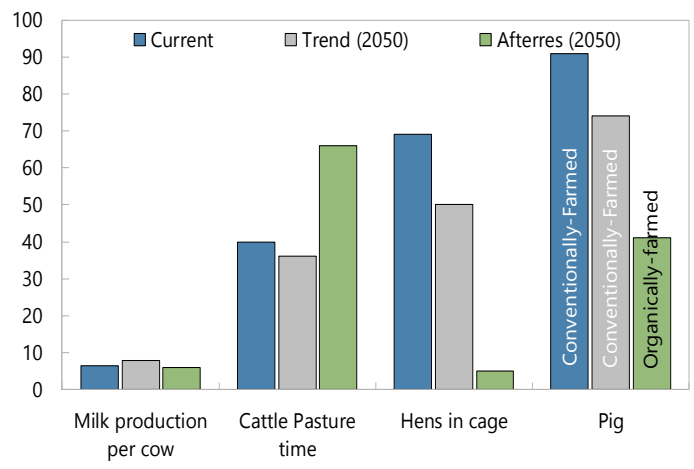

Source: Afterres2050, Solagro (2013).

Currently, the French diet is heavy on dairy and meat.

Current French Diet

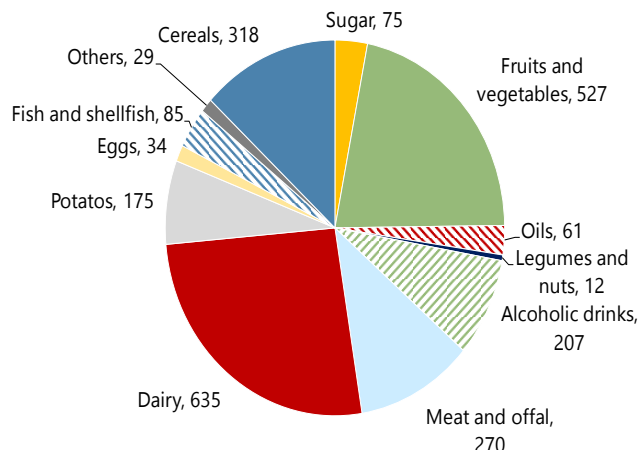

Sources: ADEME, 2016; Solagro, 2016. ....alongside a better use of renewable energy in and from agriculture.

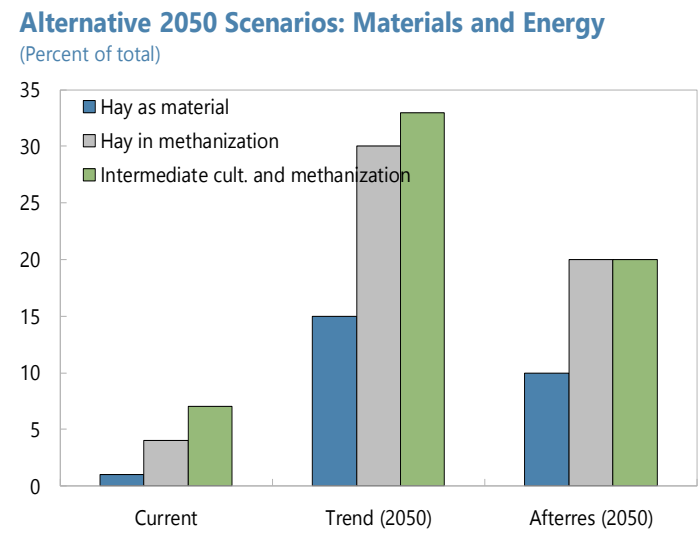

Source: Afterres2050, Solagro (2013).

This scenario promises both economic, public health and environmental gains.

Production, Exports and Environmental Gains with Afterres2050 (Percent Cumulative)

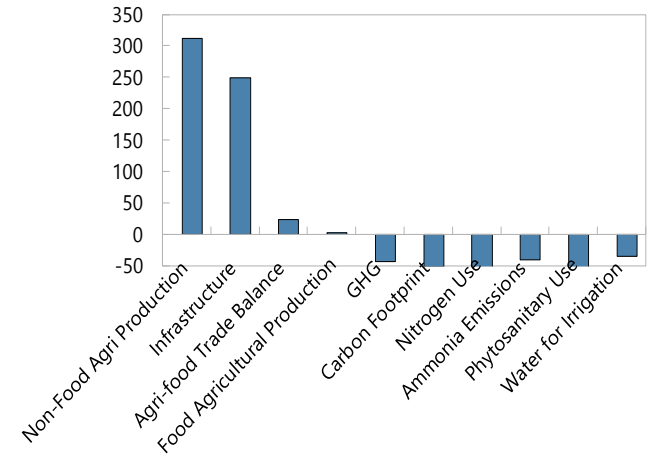

Source: Solagro, 2013. (For 2050, bars show Afterres' Minus Trend Differences)

Afterres2050 suggests a diet where plant-based foods become considerably more important.

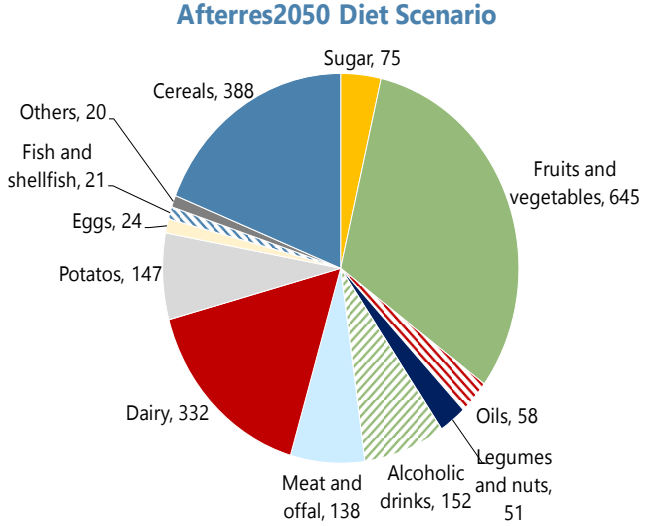

Source: Solagro, 2016 
26. On the public health, and correspondingly, fiscal front, the literature suggests that a shift in diets to accompany the shift in agri-food supply could reduce morbidity and mortality, cut health spending and raise labor productivity. Modifying the French diet to bring it in line with WHO-recommended caloric and food nutrients values could potentially reduce the prevalence of non-communicable diseases (NCD). Specifically, a shift in French diets to embrace WHO dietary recommendations could reduce diabetes Type II, CDV and cancer controllable risk factors to a large extent, controlling for other risk factors (WHO, 2004; Puska, 2014). In turn this could:

- Boost labor factor productivity and potential growth. Lower morbidity and premature mortality rates associated with NCDs would reduce France's total population disability-life years lost or years lost to premature death with a direct positive impact on France's labor productivity and growth, with the latter equivalent to about $2 \frac{1 / 4}{4}$ percent of GDP per year (50 billion euros); ${ }^{30}$

- $\quad$ Save public money structurally. Assuming that total health costs for these diseases dropped in proportion to the expected lower prevalence of the diseases in line with lower risk factors, suggests that structural fiscal saving of up to $4 \frac{1}{2}$ percent of GDP could be generated yearly on public health spending alone in the long run. ${ }^{31}$

\section{Taken together, the overall} economic gain of a shift in the French agri-food system can be estimated to be between 4 and 9 percent of GDP per year. This is obtained by summing the weighted absolute values in the literature of externalities, productivity gains and fiscal savings from a simultaneous modification in methods and volumes of agri-food production and a modification of the type and quantity of food consumed (more details of the exact calculation can be found in the footnote below). ${ }^{32}$ Using empirical

\footnotetext{
${ }^{30}$ See the report of the European Cardiovascular Disease Statistics, 2017. This is measured as the non-health opportunity cost of the probability of reduction in morbidity and mortality rates associated with dietary-riskrelated non-communicable diseases (Figure 6).

${ }^{31}$ Ibidem.

${ }^{32}$ All estimates in the above in-text table are based on France-specific estimates. The low estimate is obtained by adding — on the production side - (i) the 'low' estimate of the agri-food production externality in Ba et al. (2015) divided by $2-3$ (€7bn), which represents the amount of externalities that can be eliminated through the Afterres2050 shift scenario; (ii) the low productivity total-economy gains job scenario in Quiron (2013) embedded in Solagro (2013) (€5bn), and (iii) half the externality cost of food waste in ADEME (2016) (€5bn), assuming that only a portion of food waste and loss can be eliminated through regulatory and other external incentives. On the consumption side, the low estimate adds (i) half the public health and non-health costs associated with NCDs from the CDS (2017) on the assumption that the shift in diets would lower costs only in proportion to half of the WHO-estimated probability of reducing morbidity and mortality through a change in diets. The 'high' estimate adds the corresponding 'high' or 'full' estimates (divided by 2-3 in the production externalities' case) drawing these from the same sources quoted above (these are equal respectively to $€ 37 \mathrm{bn}$, $€ 11.2 \mathrm{bn}$ and $€ 10 \mathrm{bn})$.
} 
elasticities in simulation, these estimates account for shifts in prices generated by the change in demand and supply and include the necessary price/quantity adjustments of international trade on the production side (see Solagro 2013 and 2016). While these estimates are subject to uncertainty, refer to medium to long-run gains and ignore near-term transitional costs, they suggest that reforming the agri-food sector promises large potential gains, especially considered that these estimates do not account for the impact on economic growth of avoiding future resource scarcity and an escalation in anti-microbial resistance. The estimate also ignores the disutility of illness, and the opportunity costs of an efficient use of resources wasted for food loss and health expenditure in preventable diseases associated with the current agri-food system.

\section{CURRENT AGRICULTURAL POLICY}

28. As a member of the EU, French agricultural production is subject to the EU's Common Agricultural Policy (CAP), and it is thus heavily affected by changes to the CAP. ${ }^{33}$ Introduced in 1962, the CAP has undergone several changes since then to reduce the cost (from 71 percent of the EU budget in 1984 to 39 percent in 2013) and to also consider rural development in its aims. The CAP works through a system of agricultural subsidies and price/market support programs and has long exerted a strong influence on agricultural and land change practices in Europe. Annex I, appended to the paper, describes in detail how the CAP works and what are the policy changes occurred with the introduction of the most recent, 2014-2020 CAP budget.

29. Over time, the CAP has become more environmentally-friendly, pushing France and other countries to make its agriculture sector greener and more equitable. Over the last two decades, the CAP has undergone a gradual change from market intervention instruments (e.g. price support) to farm-specific measures attempting to enhance the environmental performance (notably the sound management of natural resources, spatial planning and respect for animal welfare) of the EU agricultural sector. This became evident with the introduction of farm-specific decoupled direct payments (i.e. the Single Payment Scheme) in 2004. A particularly strong shift towards farm-specific policy instruments occurred with the adoption of the so-called greening measures in the 2013 CAP reform. CAP greening includes environment-friendly measures that are obligatory for farmers who wish to receive full direct payments (EU, 2013; Erjavec and Lovec, 2017).

30. Currently, the CAP's budget and objectives are under discussion, posing some downside risks to the momentum behind agricultural greening. Under the current budget (2014-2020), 30 percent of direct CAP payments to farmers (which make up about 80 percent of CAP funding) are conditional on meeting minimum environmental standards. This is by far the largest EU funding stream dedicated to environmental protection. New conditionality rules are presently being discussed ahead of the agreement on the 2021-2027 EU CAP budget, and there is a chance that losses to the budget from Brexit could be met

\footnotetext{
${ }^{33}$ In the EU there are 22 million farmers and agricultural workers, and around 44 million jobs in food processing, food retail and food services depend on agriculture, making the agri-food sector one of the biggest economic sectors in the EU. The EU is also a net exporter of food and drink, exporting goods for more than $€ 130$ billion per year (see, EU, 2018 "CAP at a Glance”, https://ec.europa.eu/agriculture/cap-overview en).
} 
through cuts to agricultural subsidies. Lessening of the current CAP support for environment-friendly agricultural practices could make it harder for France to comply with their international commitments under the 2030 Sustainable Development Agenda, the UN Convention on Biological Diversity, and the Paris Agreement.

\section{At home, France has launched a series of domestically-funded ambitious} production greening initiatives, including in agriculture. On September 2017, the government launched the Big Investment Plan (Grand Plan d'Investissment, henceforth GPI) with the cross-cutting objective to boost public investment for a more transformative, concrete and forward-looking public action on the country's economic priorities for the future. Emphasizing the importance of agriculture as guarantor of food security, provider of activity in rural and ancillary agro-food jobs, and as main positive contributor to the balance of trade and the influence of France in the world, the GPI dedicates 5 billion euros to accelerate the adaptation of tools and the change in practices of agriculture, fisheries, agri-food and the forest-wood sector, which it considers "essential sectors" to be transformed in the government's quest for faster and better productive innovation. Additional funding ( 7 billion euros) under the plan targets innovation in renewable energy to accelerate ecological transition, including via the enhancement of a circular economy in agriculture via the development of alternative energy sources like biomasses, to finance a 70 percent increase in the renewable energy production capacity. ${ }^{34}$ These plans have been accompanied by regulatory non-mandatory measures for the sector in 2008, 2017 and 2018 to shelter biodiversity and reduce the use of pesticides, the latter met initially with mixed success. ${ }^{35}$

32. Precise initiatives under the GPI have been discussed in the context of the 2017 government-organized Food General Assembly (Etats Generaux de l'Alimentacion, henceforth 'EGA'). Opened by the Prime Minister on July 20, 2017, EGA were closed on December 21 and aimed to market more equitable for suppliers and consumers, green agri-food production, and making food safer and healthier. From the EGA, a bill proposal (see Box 2) emerged which was approved and became law on October 30, 2018. The law is structured around three strategic axes: (i) ensuring the food sovereignty of France; (ii) promoting healthy food choices that respect the environment; (iii) reduce inequalities in access to sustainable and quality food.

\section{On the agri-food demand front, the government is also working on} strengthening dietary recommendations through its 2017-21 National Health Nutrition Program (PNNS). Launched originally in January 2001, and renewed in 2006 and 2011, the plan has the general objective of improving the health status of the entire population by acting on nutrition. In 2017, the High Council for Health (Haut Counseil de Santé, HCH)

\footnotetext{
${ }^{34}$ See http://agriculture.gouv.fr/grand-plan-dinvestissement-5-milliards-deuros-pour-lagriculture.

${ }^{35}$ Alongside, in July 2018, the government has launched a plan to accelerate biodiversity preservation targets which sets targets for agricultural land use (Plan Biodiversite) to accelerate France's biodiversity international commitments spelled out in 2017 under the Stratégie Nationale pour la Biodiversité (SNB 2011-2020). See https://www.ecologique-solidaire.gouv.fr/plan-biodiversite. The government has also launched plans to reduce the use of pesticide use, in line with EU Pesticides Directive (Directive 2009/128/CE du Parlement européen et du Conseil du 21 octobre 2009), under the plans Ecophyto I and II. (See http://agriculture.gouv.fr/sites/minagri/files/151022_ecophyto.pdf and Guichard et al. 2017).
} 
conducted an evaluation of the processes and results of the three previous PNNSs, finding their strategies - based primarily on nutrition communication and incentive approaches - in general only in part effective, while finding them ineffective at reducing social inequalities in health in the area of nutrition. Against this background, the $\mathrm{HCH}$ has proposed specific regulatory measures to facilitate individual choices favorable to health including reducing the pressure of commercial marketing, improve the food supply and the physical and economic accessibility of foods of better nutritional quality. Lastly, it recommended developing specific and priority actions aimed at children and disadvantaged populations. This work interfaces with other public actions in the area of food and diets, notably the yearly National Food Plans (Programme National pour l'Alimentacion, PNA), the Regional Plan for Sustainable Agriculture (Plan Regional de l'Agriculture Durable, PRAD) and the Territorial Nutritional Projects (Projet Alimentaire Territorial, PAT) launched in 2018 with the aim of creating collaborations between producers and consumers in the various French regions for the development of healthy, equitable, no-waste, and locally-farmed food..$^{36}$

\footnotetext{
${ }^{36}$ Both the PNA (associated to the PNNS) and the PRAD have been instructed under the Loi de la Modernisation de l'Agriculture et de la Peche of 2010 and are governed by the Ministry of Agriculture's Direction Generale de l'Alimentacion with the aim of supporting food security and sustainable agriculture. The PAT have been instructed by a follow-up law in 2014 (No. 2014-1170) in the same spirit but with a more local focus.
} 


\section{Box 2: Objectives and Measures of the Agricultural and Food Bill \\ (Loi Agriculture et Alimentation)}

The government has drafted an Agricultural and Food Bill (Loi Agriculture et Alimentation) to improve the way the French agri-food market work. The bill aims to market more equitable for suppliers and consumers, green agri-food production, and making food safer and healthier. The bill proposal, already debated in parliament and expected to become law in the Fall of 2018, is based on a consultative process with all stakeholders (Food General Assembly, 'EGA') that took place over several months between end 2017 and early 2018. Key steps summarized in the law include:

- $\quad$ Pricing. Modifications to the agricultural pricing process to better reflect production costs (Articles 1 to 3 ) and facilitation and reinforcement of agricultural mediation to ensure a better distribution of the value created between the actors (Articles 4 and 5).

- $\quad$ Competition. Introduction of limits to price promotions to end food price wars and prohibition for retailers to sell below the actual purchase price plus $10 \%$ to fight against price deflation and ensure a fair distribution of value (Article 15 and 16).

- $\quad$ Public catering. Mandatory requirement for public canteens including schools to serve 50 percent of all food to be organic, local or produced with environmentally-friendly by 2022 to make collective catering a lever for improving the quality of food (Article 24).

- $\quad$ Food waste. Reduction of food waste in collective catering through the introduction of a mandatory diagnosis and food donation, which is extended to collective catering and the food industry to fight against food insecurity and limit the environmental consequences of waste (Article 88).

- $\quad$ Animal welfare. Extension of the offense of animal abuse and doubling of penalties. Animal welfare associations may bring civil action in the cases punishable under the Rural Code and the Sea Fishery and found by an official control (to strengthen of measures in the field of animal welfare) (Articles 67 to 73).

- $\quad$ Sales and use of pesticides and herbicides. Reduction in dependence of agriculture on phytosanitary products. Separation of sales and consultancy activities in the marketing of plant protection products, and mandatory prescriptions for the use of saving certificates in plant protection products. Discounts, rebates and rebates on the sale of these products are prohibited (Articles 74 to 77 ).

- Monitoring. The powers of investigation and control of health protection, animal protection and food safety officers are strengthened (Article 83).

34. France is a leader in the EU debate on improving diets and health. France is an active member of the Joint Action Nutrition and Physical Activity group (JANPA), ${ }^{37}$ a high level group on nutrition and physical activity created by the European Commission (EC) in 2007 with the aim to help stop the increase in overweight and obesity in Europe by 2020 within the general framework set by the European Plan of Action on Obesity of the Child, and has been coordinating it since September 2015. ${ }^{38}$ The key goals of the group are to help promote the right nutrition in schools and by allowing to test the feasibility of launching a European-level Food Observatory on the blueprint of the French Food Observatory in order to develop a detailed knowledge of the variability of the nutritional composition of foods and encourage producers to make nutritional improvements.

\footnotetext{
${ }^{37}$ The JANPA, which is 60 percent funded by the EC, allows Member States to work together towards a common goal, while remaining within the framework of their national health policy. It brings together 39 institutions from 25 countries of the European Union plus Norway. The WHO Europe Office is an associate partner. Apart from the transversal work packages (coordination, dissemination and evaluation), JANPA relies on 4 technical work packages relating to "economic proofs and justifications for action on childhood obesity". monitoring nutritional information and stimulating reformulation "," healthy environments through integrated approaches in the school setting "and finally" early interventions for pregnant women and young children". The issue of social inequalities in health in nutrition is a cross-cutting issue raised in every work package.

${ }^{38}$ The action is coordinated by France's DGS and National Agency for Sanitary Safety of Food, Environment and Labor.
} 


\section{ENABLING THE SHIFT: WHAT POLICY LEVERS?}

35. The government's recent initiatives under the GPI for Agriculture and the Agriculture and Food Bill are both innovative, timely and welcome. While the GPI focuses on greening production, by boosting public investment to support the transition of agriculture, fisheries, agri-food and the forest-wood sector towards sustainable practices and healthier produce, the Agriculture and Food Bill relies on a mix of regulatory changes to strengthen existing health and safety rules, foster the demand (and, thus, supply) of sustainable food, and discourage the overuse of phytosanitary products in conventional farming - all important steps to reduce the environmental and public health externalities arising from the current French agri-food market in line also with recommendations by the $\mathrm{HCH}$ under the new 2017-2021 PNNS.

36. Additional, well-focused measures could reinforce government action and help frontload the reform's macroeconomic and environmental benefits. Fiscal and structural reform measures used successfully in other markets to affect supply and demand allocations (for example to shift supply of energy toward cleaner sources) could be deployed alongside recent initiatives to accelerate the shift of supply and demand in the agri-food markets, to arrive sooner at more sustainable production and healthier diets nationwide and reap the gains of this transition sooner and more fully.

37. Existing French-specific mitigation scenarios could be used to set up production and consumption targets for the agri-food market in 2030 and 2050. Among these Afterres2050, the most comprehensive study currently available, could provide both practical benchmarks for interim (2030) and final (2050) supply and demand levels and an analysis of socio-economic outcome associated in expectation with the recommended sectoral shift. The Afterres 2050 scenario has been used to inform sectoral policies already in France and is the only plausibly capable of delivering the government environmental targets and a series of direct and indirect macroeconomic gains (see Box 2).

38. Delivering production and consumption targets can be achieved using demand and structural reform policy levers from a dedicated toolkit comprising measures to shift both supply and demand. While the single supply-side and demand-side measures can be used individually or in combination, both the supply and demand of agri-food must shift to arrive at the new desired equilibrium. A shift in supply only would be unprofitable for producers absent demand; and a shift in demand in the absence of sufficient supply could cause an increase in agri-food prices and a fall in households' purchasing power.

39. The policy toolkit should include both fiscal and structural reform measures. The current configuration of agri-food market equilibrium is the result of a multitude of factors, and therefore no single solution is likely to be effective in shifting supply and demand to deliver the new desired equilibrium. Both on the supply and demand side, a range of interventions that financially motivate (fiscal levers), nudge and empower (structural reforms) firms and individuals to make the required behavioral changes will be necessary. These interventions need to be systematic, not only aiming for an immediate impact on the net energy balance but also making sure that change is sustained. A comprehensive portfolio of interventions is also required to target the different needs and responsiveness of various 
population segments. The government, the healthcare system, producers, employers, retailers, consumer-goods companies, and consumers themselves all need to play their part.

40. On the supply side, fiscal measures to shift supply may include adjustments to both taxes and subsidies. Tax adjustments should focus on calibrating direct and indirect taxes and social security contributions (SSC) on agri-food production and agri-food sales based on the level of externalities these generate. For example, net profits from conventional farming should be taxed more than net profits from organic farming, as the former's externalities are several orders of magnitude larger than the latter's. ${ }^{39}$ By the same token, subsidies' adjustments should aim at recalibrating the system of subsidies to agri-food production to better reflect the level of externalities it generates. For example, crops that are under produced relative to the targets under the transition scenario should be subsidized more relative to crops the production of which exceeds indicated transitional targets.

\section{To this end, on the tax and payroll contribution front, several fiscal options are} at hand. ${ }^{40}$ Building on the already existing differential tax treatment across agricultural products, farming structure and income, as well as the existing agricultural-specific social security system, gradual parametric modifications can be introduced to agriculture's tax system so as to scale fiscal obligations in proportion of the level of externalities generated by each productive activity. ${ }^{41}$ Accounting for supply elasticities to fiscal costs, these modifications can be devised to be cumulatively fiscally-neutral in the new production equilibrium.

\section{Analogously to the approach taken for the promotion of clean energy, such modifications to the agricultural tax structure can simultaneously help engineer a} targeted shift in: (i) the type of farm animals bred (for example, by reducing the taxation from income and value added generated by rearing and selling more sustainable animals like pigs and poultry relative to the taxation levied on breeding bovines, which are considerably less sustainable); ${ }^{42}$ (ii) the way farm animals are bred (for example, by reducing the relative taxation on income from selling animals reared organically and with longer pasture exposure); and (iii) the type of crops farmed (for example, by reducing the taxation from income generated producing leguminous, pulses and cereals relative to that on income from producing less sustainable produces, like potatoes and sugar $)^{43}$ to deliver new desired

\footnotetext{
${ }^{39}$ This measure is partly already at work through the tax credit for organic farming on both income and corporate tax. However, currently the measure is rather limited ( $€ 3500$ per year per farm, up from $€ 2500$ before 2018), and is set to expire in 2020. In general, integrating environmental charges into profit taxes is complicated as to be efficient these charges would ideally be specific and related to external costs (and invariant to prices and profits).

${ }^{40}$ On the general case for, and design of, environmental taxes see Parry, Ian W.H., Dirk Heine, Shanjun Li, and Eliza Lis, 2014, Getting Energy Prices Right. Washington: International Monetary Fund.

${ }^{41}$ This would be administratively practical once production has been categorized in base of externalities.

${ }^{42}$ In countries where imports of bovine meat are high, these differentials in taxation between bovine and other meats are better implemented on the final product (meat), but this is not the case of France.

${ }^{43}$ Sugar beets and citrus crops, followed by vegetables, tubers, and grains are, consume the highest level of nitrogen, phosphate, and potash fertilizer per acre of cultivation. Peas and beans require just a fraction of these fertilizers per acre, in part because they have capacity to absorb nitrogen from the air.
} 
national production and consumption equilibria. Parametric tax and social contributions modifications can also be introduced to favor smaller, polyculture farming activities or farms with a higher labor-to-acre ratio vis-á-vis large, monoculture, highly-mechanized farms, which tend to follow less sustainable production methods. ${ }^{44}$

\section{Likewise, various options are available to modify the allocation of CAP subsidies} in support of more sustainable production. While the overall envelope and general guidelines governing CAP subsidies depend on the EU's collective policy decisions ${ }^{45}$ the CAP offers considerable flexibility in the allocation of subsidies to member countries in the context of both Pillar 1 - funded by the European Agricultural Guarantee Fund (EAGF) and Pillar 2 - that is based on Rural Development Programs (RDPs) co-financed by the European Agricultural Fund for Rural Development (EAFRD) and EU Member States (see Annex 1 for more details). It follows that a large share of France's CAP entitlements (the largest in the EU, at around $1 / 5$ of the total CAP budget, of which only 2 percent presently go to organic farming) can potentially be gradually redirected to help generate the new pursued market equilibrium. Main areas of flexibility include:

- Transfer of funds between Pillar 1 and 2 or vice versa to shift support in favor of low- or no-externality-generating activities;

- Targeting to desired commodities commodity-specific payments funded from the national budget in addition to SAPS aid, including through the transitional national aid (TNA) scheme; ${ }^{46}$

- $\quad$ Leveraging of rules under the CAP's new voluntary coupled support (VCS) to allocate a larger subsidy envelope to desired production (i.e. low-externality crops and breeds) sub-sectors or regions (to better tailor the use of indigenous resources/energy to low-externality crops and breeds).

\section{In the long-run, the shift in national allocation of CAP subsidies should reflect desired equilibrium supply allocations. During the transition to the new production equilibrium, however, a greater-than-proportional allocation may be necessary to help a sufficient number of sustainable farmers enter the market and become profitable.}

\footnotetext{
${ }^{44}$ See Barbieri, Pellerin and Nesme (2017). Comparing conventional with smaller-scale polyculture farms in the United States, Montgomery (2018) concludes that well-managed alternative farming systems nearly always use less synthetic chemical pesticides, fertilizers, and antibiotics per unit of production than conventional farms.

45 The European Agricultural Guidance and Guarantee Fund (EAGGF) of the EU, which used to fund the CAP has been replaced in 2007 with the European Agricultural Guarantee Fund (EAGF) and the European Agricultural Fund for Rural Development (EAFRD). CAP reform has steadily lowered its share of the EU budget but it still accounts for nearly half of the EU expenditure. France is the biggest beneficiary of the policy by around 20 percent, followed by Germany and Spain (around 13 percent each), Italy (around 11 percent) and the UK (around 9 percent).

46 TNA payments can be disbursed as decoupled payments while a fixed share may be spent on current production. They may apply on a per area basis to arable land, hop and starch potatoes, on a volume basis to milk and on a head-age basis to other livestock. Member States may review TNA budgets and supported commodities on an annual basis. The maximum TNA payments allowed falls gradually from 75 percent of the 2013-level of SAPS aid in 2015 to 50 percent in 2020.
} 


\section{Supply-side structural reforms to shift supply could include a combination of} regulatory, education-reinforcing and financial incentivizing steps. Prominent examples comprise:

- Incentives through conceptualization, education, training and dedicated administrative simplification for all voluntary greening schemes beyond those linked to direct payments under the CAP and in line with the "4\%o Initiative" under the 2015 Lima Paris Agenda for Action (LPAA) and, more generally, the recommendations of the French High Council for Food, Agriculture and Rural Areas (Conseil Général de l'Alimentation, de l'Agriculture et des Espaces Ruraux, CGAAER);

- Introducing food-waste reduction schemes beyond collective catering as provided in the recent Loi Agriculture et Alimentation;

- $\quad$ Sponsoring food-industry businesses initiatives to research, test and scale up new strategies and plans that help consumers select healthy and sustainable foods in line with recommendations, for example, of the World Resource Institute's Better-Buying $\mathrm{Lab}^{47}$

46. On the demand side, fiscal measures to shift the type, combination and quantity of food that French citizens demand may include, like on the supply side, tax and subsidy adjustments. Tax measures should focus on recalibrating indirect taxes on consumption and retailing based on the level of externalities these generate. Tax credits could be introduced to offset the potential extra tax burden on each taxpaying individual or family (after adjusting for lower consumption) from the recalibration of indirect taxes, so that consumers' ability to eat will not be diminished. On the spending side, public-financed canteens (not just schools as provided under the Loi Agriculture et Alimentation, see Box 3) should reorient their demand to minimize externalities from their consumption, thereby supporting the development and profitability of the emergent French low-externality agri-food market. ${ }^{48}$

\section{For example, a (Pigouvian) ${ }^{49}$ tax on foods associated with high negative} environmental and public health externalities could be introduced, calibrated to the elasticity of French-specific demand and the desired quantity equilibrium for these foods, along the lines of what proposed by Simon (2014) and Joyner and Warner (2015) for the United States. The success of these taxes in shifting consumption is well known for tobacco

\footnotetext{
${ }^{47}$ https://www.wri.org/our-work/project/better-buying-lab.

${ }^{48}$ Switching the food offer at public canteens toward organic food may imply transitionally higher spending all other policies staying equal, but it would not if, for example, value added taxes were cut relative to value added taxes on non-organic food, proportionally. More generally all the measures suggested can be designed to ensure that the overall reform is budget neutral in the near term.

${ }^{49}$ A Pigovian tax - from Arthur Pigou, a Cambridge University professor active in the first half of the 20th century--adjusts the market for goods that cause externalities by raising the goods' costs and thereby reducing demand for them. Such a tax pays a double dividend by both generating revenue and reducing undesirable consumption. Ideally, the new revenue adds to — or replaces - general tax revenue and thus can be used to lower general taxes.
} 
smoking and alcohol, and recent evidence is emerging on their effectiveness in curbing the consumption of carbonated drinks, for example in Chile and Oman, where 'sin' taxes to shift buying habits away from these goods were introduced in 2011 and 2017, respectively. Beyond the boost to fiscal revenues, this change could give consumers more accurate price signals about the true social cost of their food consumption choices, and potentially lead to a shift in consumption patterns. ${ }^{50}$

\section{Tax credits could be introduced in parallel, to offset the cost of the high- negative-externalities produces tax to individual taxpayers, as suggested by Simon} (2014). Tax credits would offset the extra tax burden on each taxpaying individual or family (after adjusting for lower consumption), so that consumers' purchasing power will not be diminished, while they would better perceive the externality cost of different food products which would help them orient them in their consumption behavior. It would also make healthier (more plant-based and organic-food based) diets more affordable for lower earning households relative to less healthy food, chipping at health inequalities related to income disparities. Further, while fiscally-neutral, the spending-related stimulus would help offset the lower spending caused by other parts of the policy plan. Importantly, flanking the meat and dairy tax with a direct benefit to individuals would lessen the political economy challenge of a new tax, motivating voters and lawmakers to support the overall plan. The credit could be funneled via tax credits on specific foods to ensure proper targeting to consumers that have embarked in an actual demand shift toward sustainable produces.

\section{Non-fiscal measures to shift demand include:}

- $\quad$ Recurrent public campaigns to raise awareness about the public health and environmental impact of alternative food choices beyond existing government plans;

- Introduction of more ambitious mandatory targets for the type, combination and quantity of food served in public canteens;

- $\quad$ Regulatory marketing and retailing reforms to encourage the demand of externalityfree food demand and/or discourage the demand for externality-generating food;

- Health system reform to better incorporate lifestyle choices recommendations in preventive and therapeutic health protocols.

\footnotetext{
${ }^{50}$ Taxing authorities around the world have successfully used Pigouvian taxes in a variety of ways. Most notable, perhaps, are programs that use tobacco taxes or taxes on alcohol to reduce cigarette smoking or alcohol consumption and increase tax revenues. Just as it has for cigarettes and alcohol, a tax on high-externality foods would pay a double dividend by simultaneously boosting revenues and lowering consumption (and related social problems). Research shows that, while possibly not immediately effective at curbing undesired consumption - as some 'sin' tax experiments on fat and sugary food, for example, in Denmark, indicatePigouvian taxes on food may work well in the long run -with findings indicating that a 10 percent increase in the price of calories results in a fall in the body-mass index (BMI) of one to two points over 20 to 30 years (Rand, 2017). For the United States, for example, where the consumption of meat and dairy is considerably higher than in France, Simon (2014) calculates that the combination of curtailing subsidies to industrial animal food production, introducing a 50 percent tax on meat and dairy and excluding animal food from food support programs in the US would reduce meat and dairy consumption by about $1 / 2$.
} 
50. The right combination and calibration of policy measures to deliver the desired targets will depend on agri-food price and quantity elasticities given the overall policy package. It is hard to determine ex ante what the exact configuration of the most effective portfolio of policy interventions may be and this is thus likely to need some trial and error. However, looking at the experience with policies across the world aimed at eliminating negative externalities in other markets, and to existing government action in the same French agri-food sector, such an agenda looks promising.

\section{CONCLUSIONS}

51. French agriculture is macro relevant for France and the $\mathbf{E U}$ and generates important externalities. France is the number one agricultural producer in the EU, and a major world exporter of agricultural commodities, meaning that the sector plays a prominent role in the country's foreign trade and intermediate exchanges. Reflecting production volumes and methods, the sector, however, also generates significant negative environmental and public health externalities.

52. Reforming agriculture is important because it can achieve many economic, social and ecological goals simultaneously. A well-designed shift in agri-food to make production sustainable and consumption healthier would preserve this primacy, benefit the economy and help deliver France's domestic and international environment and health targets. In the absence of these shift, by contrast, both France's export primacy and such targets would be in jeopardy.

53. With this awareness, the government has already studied and debated alternative reforms for the sector. The paper reviews alternative, French-specific, recently-elaborated shift scenarios for the agri-food sector, which provide actionable targets for a shift by 2030 and/or 2050. It then discusses their corresponding environmental, macroeconomic and public health/fiscal gains.

54. A conservative estimate of economic gains from reforming the agri-food sector points to significant potential growth gains and fiscal savings. By looking at prior empirical estimates of production and consumption externalities, the overall macroeconomic gain of transforming the sector to meet the government's environmental targets is estimated to be between 4 and 9 percent of GDP per year. While these estimates are subject to uncertainty and focus on long-term gains, they are sizeable: the upper figure is equivalent to three times annual public investment, or 1/3 of the annual GDP of the Île-de-France. These figures also underestimate actual potential gains because they exclude the advantages from eliminating a number of externalities that are hard to cost, like the disutility of illness and for example, the costs, to France, of an escalation in antimicrobial resistance related to French policy inaction vis-à-vis alternative policy action scenarios in other countries.

55. Several effective policy tools are at hand to accelerate its existing ambitious reform agenda. The government's innovative and timely recent initiatives to reform the sector could be reinforced by a set of fiscal and structural reform measures to attain targets and reap benefits sooner. The paper suggests several key measures, including carefully 
calibrated taxes and subsidies to shift demand and supply (at all levels of production and consumption) in proportion to their contribution to the sector's externalities; changes to the way CAP subsidies are allocated in France once received; and structural reforms to encourage and empower firms and individuals to make the required behavioral changes necessary to implement change. Changes to taxes and subsidies as well as public expenses needed to drive the reforms proposed can be calibrated to make the advocated additional reform steps budget neutral in the near term.

56. The effectiveness of these tools at reforming the sector is promising. Examples of policies aimed at eliminating negative externalities in other markets suggest that significant results may be in store by applying recommended policies, provided that the measures to reform the sector are combined and calibrated effectively. To this end, more analysis is needed to quantify French-specific price and quantity elasticities in the agri-food market and guide the appropriate calibration of the recommended policy measures. 


\section{REFERENCES}

Agence de l'environnement et de la maîtrise de l'énergie (ADEME), 2013. "Visions Energie-Climat 2030-2050”.

_, 2016 . "Pertes et gaspillages alimentaires: l'état des lieux et sa gestion aux différentes étapes de la chaîne alimentaire".

Agence nationale de sécurité sanitaire de l'alimentation, de l'environnement et du travail (ANSES), 2017, "INCA3: Étude individuelle nationale des consommations alimentaires 3".

Bâ, Maïmouna, Mathilde Gresset-Bourgeois, and Philippe Quirion, 2015. "Combien coûte la pollution agricole en France ? Une synthèse des études existantes". French Association of Environmental and resource Economists, FAERE (http://faere.fr/en/publications-2/press-opinions-debates/).

Barbieri, Pietro, Sylvain Pellerin and Thomas Nesme, 2017. Comparing crop rotations between organic and conventional farming ». Nature, Scientific Reports (7), Article number: 13761 (2017)

Carlet, Jean, and Pierre Le Coz, 2015. "Together let's save antibiotics: report for the special working group for keeping antibiotics effective." (http://social sante.gouv.fr/IMG/pdf/rapport_antibiotiques.pdf).

Chambres d'Agriculture France, 2018, "Fiscalité et cotisations sociales" (http://chambres-agriculture.fr/exploitation-agricole/gerer-son-entreprise-agricole/fiscalite-etcotisations-sociales/).

Dauce' Pierre, 2015. Agriculture et le monde agricole. La Documentacion Française.

de Lagasnerie G, Aguadé AS, Denis P, Fagot-Campagna A, Gastaldi-Menager C, 2018. "The economic burden of diabetes to French national health insurance: a new cost-ofillness method based on a combined medicalized and incremental approach". European Journal of Health Economics, 19(2):189-201.

Desriers, Maurice, 2007. "L'agriculture française depuis cinquante ans : des petites exploitations familiales aux droits à paiement unique". INSEE: L'agriculture française et l'Europe in L'agriculture, nouveaux défis - édition 2007

European Food and Safety Authority (EFSA), 2018. The European Union summary report on antimicrobial resistance in zoonotic and indicator bacteria from humans, animals and food in 2016. EFSA Journal 16(2):5182.

Erjavec, Emil, and Marko Lovec, 2017. "Research of European Union's Common Agricultural Policy: disciplinary boundaries and beyond." European Review of Agricultural Economics, 44(4):732-754. 
EU, European Parliament Research Service (EPRS), 2017. EU Action on Cancer.

EU Fusions Project, 2016 (project contributors: Stenmarck, Asa, Carl Jensen, Tom Quested, Graham Moates. Estimates of European food waste levels. (https://www.eufusions.org/).

European Union, 2013. Regulation No. 1307/2013 of the European Parliament and of the Council of 17 December 2013 Establishing Rules for Direct Payments to Farmers under Support Schemes within the Framework of the Common Agricultural Policy and Repealing Council Regulation (EC) No. 2013 637/2008 and Council Regulation (EC) No 73/2009. Official Journal of the European Union L 347/608.

European Cardiovascular Disease Network, 2017. 2017 Report.

European Union-World Health Organization, 2014. European Plan of Action on Childhood Obesity 2014-2020.

Eurostat, 2018. Farm Structure Survey 2013. https://ec.europa.eu/eurostat/statisticsexplained/index.php/Farm_structure_survey_2013_-_main_results

Gazan R, Béchaux C, Crépet A, Sirot V, Drouillet-Pinard P, Dubuisson C, Havard S, 2016. "Dietary patterns in the French adult population: a study from the second French national cross-sectional dietary survey (INCA2) (2006-2007)." The British Journal of Nutrition, 116(2):300-15.

Gran Plan d'Investisstment 2018-2022: http://agriculture.gouv.fr/grand-plandinvestissement-5-milliards-deuros-pour-lagriculture.

Gruber, Jonathan and Köszegi, Botond, 2001. "Is addiction "rational"? Theory and evidence". Quarterly Journal of Economics, 116(4): 1261-1303.

Guichard, Laurence, François Dedieu, Marie-Hélène Jeuffroy, Jean-Marc Meynard, Raymond Reau et Isabelle Savini, 2017. "Ecophyto, the French action plan to reduce pesticide use: a failure analyses and reasons for hoping". Cah. Agric. 26(1), 2017.

Guihardet, Veronique and Lesdos Claire, 2007. "L'agriculture sur trente ans : une analyse comparative avec l'industrie et les services". Insee: L'agriculture, nouveaux défis édition 2007.

Haut Conseil de Santé Publique (HCSP), 2017. Program National Nutrition Sante (PNNS) 2017-21.

Larochette, Brigitte et Joan Sanchez-Gonzalez, 2015. "Cinquante ans de consommation alimentaire : une croissance modérée, mais de profonds changements". Insee, Division Synthèses des Biens et Services.

Insee, 2017. Agriculture in 2016. Insee Première No. 1656. 
Institut national de la recherche agronomique (INRA) in collaboration with Ministère de la Transition Écologique et Solidale and Agence de l'environnement et de la maîtrise de l'énergie (ADEME), 2013. "How can French agriculture contribute to reducing GHG".

Institut national de la recherche agronomique (INRA), 2013. "Quelle contribution de l'agriculture française À la réduction des émissions de gaz à effet de serre? Potentiel d'atténuation et coût de dix actions techniques. Synthèse du rapport de l'étude réalisée par l'INRA pour le compte de l'ADEME, du MAAF et du MEDDE'.

Institute for Climate Economics (I4CE, Caisse des Dépôts and Agence Française de Développement-AFD), 2015. Repères - Chiffres clés du climat France et Monde Édition 2015.

International Union for Conservation in Nature (IUCN), 2013 European Union (EU) RedList, of Threatened Species.

Law, Malcom, and Nicholas Wald, 1999. Why heart disease mortality is low in France: the time lag explanation". BMJ 1999; 318:1471.

Martin, Martin, Sapna E Totthatil, and Thomas B Newman, 2015. "Antibiotics Overuse in Animal Agriculture: A Call to Action for Health Care Providers.", American Journal of Public Health, 105(12): 2409-2410

Ministere de l'Agriculture, de l'Agroalimentare ed de la Foret, 2018. Écoantibio 2 : plan national de réduction des risques d'antibiorésistance en médecine vétérinaire (20172021).

Ministere de l'Agriculture, de l'Agroalimentare ed de la Foret, Centre for Studies and Strategic Foresight (Centre d'Études et de Prospective - CEP) 2013. "Climat : vers des stratégies d'adaptation” http://agriculture.gouv.fr/Seminaire-de-restitutionAFCLIM.

—, 2013. "Agriculture énergie 2030".

- 2014, "French Agriculture and the challenge of climate change: what are the prospects for mitigating its greenhouse gas emissions”. CEP No. 73.

Ministère de la Transition Écologique et Solidale, 2017. Stratégie Nationale pour la Biodiversité (SNB).

—

- , 2018. Les impacts potentiels du changement climatique à l'horizon 2050 en France. (http://www.statistiques.developpement-durable.gouv.fr/lessentiel/ar/2533/0/impactspotentiels-changement-climatique-lhorizon-2050.html).

- 2018. Plan Biodiversité. 
O’Neill Report, 2016. "The review on antimicrobial resistance (AMR): Tackling drug-resistant infections globally: final report and recommendations" (chaired by Jim O'Neill, commissioned in 2014 by the UK Government and sponsored by the Wellcome Trust and the UK Department of Health).

OECD, 2015. The Economic Consequences of Climate Change.

OECD-FAO, 2018. Agricultural Outlook 2018-2027.

Parry, Ian W.H., Dirk Heine, Shanjun Li, and Eliza Lis, 2014, Getting Energy Prices Right. Washington: International Monetary Fund.

Perthuis Committee Report 2011, “Trajectoire 2020-2050 vers une économie sobre en carbone".

Puska, Pekka, 2014. "The Global Strategy on Diet, Physical Activity \& Health: 10 Years On." International Association of National Public Health Institutes and World Cancer Research Fund International. (https://www.wcrf.org/int/blog/articles/2014/05/globalstrategy-diet-physical-activity-health-10-years)

Roth, G. and others, 2017. "Global, Regional, and National Burden of Cardiovascular Diseases for 10 Causes, 1990 to 2015." Journal of the American College of Cardiology. 70(1):1-25 (https://www.sciencedirect.com/science/article/pii/S0735109717372443).

Rovný, Patrick, 2016. "The Analysis of Farm Population with Respect to Young Farmers in the European Union", Procedia - Social and Behavioral Sciences, 220: 391-398

Simon, David Robinson, 2014. Meatonomics.

Solagro, 2013, Afterres2050.

—, 2016, Afterres2050 version 2016.

Solagro-ISL-Oréade-Brèche, 2012. "Agriculture et facteur 4". Study commissioned by the French Environment \& Energy Management Agency and the French Ministry of Agriculture, Agrifood and Forestry.

Viscusi, William K., 1998. “Constructive cigarette regulation.” Duke Law Journal 47(6): 1095-1131. Health.

World Health Organization, 2004. Global Strategy On Diet, Physical Activity And

World Health Organization, 2015. Global Action Plan on Anti-Microbial Resistance. 